\title{
BİNGÖL ZAZA KÖYLERİNDEN EMTAĞ’DA KULLANILAN LAKAPLAR ÜZERINNE BİR İNCELEME
}

\begin{abstract}
Özet
Tabiattaki bütün canlı ve cansız varlıklar hakkında bilgi edinilmesini sağlayan, duygu, düşünce, olay ve durumları ifade etmeye yarayan unsurların başında şüphesiz isimler gelmektedir. Bir milletin kültürel geçmişini ve birikimini duygu ve düşüncelerini, inanç yapısını, olaylara karşı yaklaşım tarzını yansıtan isimler bu hususta önemlidir. İsimlerin özellikle belli bir bölümünü oluşturan kişi adları dışında, bireylerin bazı özellikleri hakkında bilgi edinilmesini sağlayan unsurlar arasında lakaplar yer almaktadır. Arapça kökenli bir kelime olan lakap bir kimseye, bir aileye kendi adından ayrı olarak sonradan takılan, o kimsenin veya o ailenin bir özelliğinden kaynaklanan ad șeklinde tarif edilebilir. Tarih boyunca farklı coğrafya ve milletlerde lakap takma geleneği var olmuștur. Bu gelenek günümüze dek süregelmiștir. Her milletin kendi kültürel yapısına göre lakap verme tarzı farklıdır.

Bu çalışmada, Bingöl'ün merkeze bağlı Zaza köylerinden biri olan Emtağ'da kullanılan lakaplar ele alınmıştır. Çalışma, kaynak kişiler tarafından derlenen veriler, nitel çalışma yöntemine dayanan yüz yüze görüşme tekniği neticesinde meydana gelmiştir. Dört mahallesi bulunan köyde yaklaşık olarak 30 kaynak kişi ile görüşme yapılmıştır. Çalışmanın giriș kısmında lakap ve lakap verme geleneğine ilişkin kısa bilgiler yer almaktadır. Akabinde Emtağ köyünde derlenen Zazaca lakapların özellikleri ve verilme nedenleri esas alınarak tasnifi yapılmıștır. Tespiti yapılan lakapların Türkçe anlamları "Grûba Xebate ya Vateyî” sözlügünden ve Abdurrahman Yllmaz tarafından hazırlanan "Zazaca-Türkçe Sözlük (Genç-Bingöl Yöresi)" adlı yüksek lisans çalıșmasından yararlanılarak yazılmıştır. Söz konusu lakapların veriliş sebebi, kaynak kişilerin verdiği bilgiler doğrultusunda değerlendirilmiştir.
\end{abstract}

Anahtar Sözcükler: Lakaplar, Emtağ Köyü, Bingöl, Zaza, Kültür.

\section{A REVIEW ON THE NICKNAMES USED IN EMTAĞ FROM BINGOL ZAZA VILLAGES}

\begin{abstract}
Providing information about all living and non-living beings in nature, and the most important elements that express feelings, thoughts, events and situations, are undoubtedly names. Names that reflect a nation's cultural background and accumulation, feelings and thoughts, belief structure, and approach to events are of particular importance in this
\end{abstract}

* Doktora, Osmangazi Üniversitesi Sosyal Bilimler Enstitüsü. ibulukgiray@gmail.com ORCID: 0000-0002-5319-2515

(Makale Gönderim Tarihi: 29.03.2021-Makale Kabul Tarihi: 07.06.2021)

DOI: https://doi.org/10.53440/bad.905359 
regard. Nicknames are among the elements that provide information about some characteristics of individuals, except for the names of individuals that make up a certain part of the names. The word nickname (lakap), which is an Arabic origin word, is defined as a name attached to a person, a family separately from their own name, originating from a characteristic of that person or that family. Throughout history, there has been a tradition of giving nicknames in different geographies and nations. This tradition has survived until today. Each nation has a different style of giving nicknames according to its own cultural structure.

This study focuses on Zazaki nicknames used in Emtağ village one of the Zaza villages of Bingöl. The study has a qualitative research method design based on data collected by source people and face- to- face interviews. Approximately 30 resource people were interviewed in the village, which has four neighborhoods. In the introduction section, brief information is given about nicknames and the tradition of giving nicknames. Subsequently, the Zazaki nicknames compiled in Emtağ village were categorized according to their characteristics and the reasons for their being attached to specific persons. The Turkish meanings of the predetermined nicknames were given through the use of Zaza-Turkish dictionary named "Grûba Xebate ya Vateyî" and the master's work by Abdurrahman Yılmaz named as "Zaza-Turkish Dictionary (Genç-Bingöl Region)". The reason for giving these nicknames was examined in line with the information provided by the source persons.

Key Words: Nickname, Emtağ Village, Bingöl, Zaza, Culture.

\section{Giriș}

İnsanlar arasında iletişimi sağlayan isimler hem kişilerin, nesnelerin ve varlıkların tanınmasına hem de zihinde çağrıştırdı̆̆ı anlam açısından bir nevi "kodlamalar" olarak düşünülebilir. Doğadaki bütün canlı ve cansız varlıklar hakkında bilgi edinilmesini sağlayan, duygu, düşünce, olay ve durumları ifade etmeye yarayan unsurların en başında isimler gelmektedir. İsimlerin alınması, seçilmesi ve verilme tarzı bir kültürün tamamen yapısıyla ilgili bir husustur. Kişiye isim verilirken din, dil, ırk, yöre, tarihi kişilik ve aile büyükleri gibi unsurlar etkilidir. Bir milletin geçmişini, kültürel seviyesini, toplumsal ve inanç yapısı hakkında bilgi elde etmeye yarayan unsurların başında isimler geldiği için bu konuda ayrı bir öneme sahiptir. Ad, Türkçe sözlükte "1. Bir kimseyi, bir şeyi anlatmaya, tanımlamaya, açıklamaya, bildirmeye yarayan söz, isim, nam. 2. Herkesçe tanınmış veya işitilmiş olma durumu. 3. Canlı ve cansız varlıkları, duygu ve düşünceleri, çeşitli durumları bildiren kelime, isim. 4. Sayma. Sayılma" şeklinde tarif edilmiştir (Türkçe Sözlük, 2015: 64). Halk bilimciler ise adı, "insanın toplumsal ve bireysel kişiliğinin yanı sıra büyüsel ve gizemsel gücünü de belirten simge" (Örnek, 1973: 11) şeklinde tanımlamışlardır. İsmin insan hayatındaki önemi yapılan araştırmalarda da yadsınamaz bir gerçek olduğu müşahede edilmiştir. Örneğin eski Mısırlarda kişinin "ben 
ve ad"dan meydana geldiği düşüncesi ileri sürülmüştür. Bütün toplumlarda herhangi birinin, bir nesnenin veya manevi bir varlığın adını anmak, onun varlığını kabul etmek anlamına gelmektedir. İslamiyet'te Allah'ın doğrudan ismi yerine Rahman, Rahim, Kerim vb. sıfatlarla anıldığı Hristiyan, Yahudilik ve diğer dinlerde de aynı tutumun sergilendiği görülmektedir (Aksan, 2003: 96).

Adın insan hayatındaki bu öneminden dolayı "ad bilimi", canlıların, nesnelerin ve kavramların, kısacası çevremizde gördüğümüz ve algıladığımız her şeyin adıyla ilgilenen bir bilim dalı olarak karşımıza çıkmaktadır (Sakaoğlu 2001: 9). Ad bilimin çeşitli alt dalları bulunmaktadır. Bunlardan birisi "anthroponymie-anthroponymy" kişi adları bilimidir. Kişi adları öteki özel isimlerin özelliklerini yansıttığı gibi filoloji, dilbilim, kültür tarihi ve halk bilimi çalışmaları açısından da önem taşımaktadır. Bir insana ad verilişi (göbek adı, ad, soyadı, takma adlar ve sanlar) ile bir ulusun kültürü arasında çok sıkı ilişkili bulunmakta ayrıca yukarıda değinildiği gibi adın insan için taşıdığı değere de ışılk tutmaktadır (Aksan, 2003: 114).

Ad "Anthroponymie" biliminin incelediği alt dallardan biri de lakap "patronymic" bilimidir. Antroponominin bir dalı olarak incelenen lakaplar hem dilbilimin hem de halkbilimin ortak çalışma alanı kapsamındadır. Konunun dilbilimini ilgilendiren yönü yazımızın kapsamında değerlendirilmeyeceği için lakapların halkbilimini ilgilendiren yönleri incelenecektir. Lakap kavramını, sözlük ve ansiklopedilerde küçük farklılıklara sahip olmakla birlikte birbirleriyle örtüşen tanımları yapılmıştır. Lakap Arapça kökenli bir sözcük olup Türk Ansiklopedisinde övme, tarif ve tanıma ile kötüleme ve hafife alma şeklinde üç amaçla kullanıldığı belirtilmektedir (Türk Ansiklopedisi 1975: 455). "Kişiye kendi adından ayrı olarak, sonradan konan ad" (Türk Ansiklopedisi, C. 22, 1975: 455). "Bir kimseye kendi adından ayrı olarak sonradan takllan ve o kimsenin bir özelliğini belirten ad" (TDE Ansiklopedisi, C.6, 1986: 61). "Bir aileye veya bir kişiye isminin dışında herhangi bir özelliğinden veya durumundan dolayı başkaları tarafindan takılmış isim" (Kaya, 2014: 491). "Bir kimseye asıl adından sonra takılan ikinci ad; şeref payesi; halife ve sultanların hâkimiyet alâmeti" (Bozkurt: 65) şeklinde açıklanmaktadır. Tüm bu tanımlar birbirlerini tamamlar niteliktedir. Bu tanımlara bakıldığında en büyük eksiklik olarak alt kültür diğer bir ifadeyle grup kültürünün dikkate alınmamasıdır. Boyraz, alt/grup kültürünü de dikkate alarak "kişiye her hangi bir özelliği dolayısılla kendi grup kültürü bağlamında sonradan verilen isimdir." (Boyraz, 1998: 113) şseklinde tanımlayarak eksikliği önemli oranda gidermiştir. 
Lakaplar yazılı ve sözlü kültürde kullanılarak günümüze kadar farklı şekil ve işlevlerde gelmiştir. Lakapların çok eski dönemlerden beri kullanıldığı tarihî kaynaklardan hareketle öğrenilmektedir. Örneğin Peygamberlere taşıdıkları vasıflardan ve Kur'an'da geçen âyetlerden hareketle çeşitli lakaplar verilmiştir. Hz. Îsâ'ya "Mesîh", "Rûhu'llâh" ve "Kelîmetu'llâh", Hz. Yûnus'a “Zünnûn”, Hz. Ya'kûb’a "İsrâil”, Hz. İbrâhim'e "Halîlu'llâh"ve Hz. Mûsâ'ya "Kelîmu'llâh" gibi lakaplar verilmiştir. Ayrıca Hz. Muhammed'e ise gençlik çağında dürüstlügünden ve güvenilirliğinden dolayı kavmi tarafından "el-Emîn" lakabı takılmış ve Kur'an'daki birçok âyetin delâletiyle "en-nebiyyü'l-ümmî, hâtemü'n-nebiyyîn, hâtemü'l-enbiyâ, seyyidü'l-mürselîn” gibi lakaplar da verilmiștir. Resûlullah'ın ashabında Hz. Ebû Bekir "el-Atîk, zü'l-Hilâl, Evvâh, es-Sıddîk, Şeyhülislâm"; Hz. Ömer "el-Fârûk" ve Hz. Ebû Bekir ile birlikte "Şeyheyn"; Hz. Osman "Zünnûreyn"; Hz. Ali "Haydar, el-Murtazâ, Esedullâhi'l-gâlib, ebû-Türâb"; gibi lakap veya unvanlar verildiği müşahede edilmektedir (Bozkurt, 2003: 65).

Lakaplar toplumun her kesimine mensup kişilere verilebilmektedir. Yukarıda zikredilen Peygamber ve Sahabe'nin yanı sıra devlet ricali için kullanılan lakaplar da vardır. Bunlardan Osmanlı Padişahları, sadrazam ve vezirleri için kullanılan lakapların bir kaçını zikredecek olursak; Osman Gazi'nin "Fahrüddin, Kara”, Orhan Bey'in “İhtiyârü'ddîn, Seyfü'ddîn”, I. Murad'a "Leysü'l-İslâm, Şihabü'ddîn”, I. Bayezid'a “Celâlü'ddîn, Seyfü'ddîn, Yıldırım”, I. Mehmed'e "Kirişçi", II. Mehmed'e "Ebû'l-feth (Fatih)”, II. Bayezid'a "Velî", Sultan Süleyman'a "Kanuni”, II. Selim'e "Sarı Selim”, II. Osman'a “Genç Osman”, IV. Mehmed'e “Avcı”, I. Mustafa ve I. İbrahim'e “Deli”, II. Mustafa'ya “Derviş" gibi lakaplar verilmiştir (Keskinkılıç, 2014: 1-22).

Osmanlı dönemi biyografik metinlerinde de lakaplara yer verilmiștir. Şakâ'iku'n Nu'mâniyye Zeyller'inde; vücudunun büyüklüğünden dolayı "Kaba Receb Efendi", ayağının yapısından dolayı "Tabanı Yassı Mehmed Paşa”, sesinden dolayı "Hüdhüd Abdulkadir Efendi", yaptığı işten dolayı "Tulumcu Hüsam” gibi birçok lakap örneği vardır (Ekinci 2014: 235).

Sözlü kültürde kazanılan, öğrenilen veya ezberlenen bilginin unutulup kaybolmaması için sürekli tekrar gerekiyor (Ong, 2010: 37). Buna bağlı olarak Boyraz, yazının egemen olduğu toplumlarda ezberin artık işlevselliğini yitireceğini, yazılı kültür güçlendikçe lakap kullanımında bir azalma olacağı hatta bir süre sonra lakapların tamamen yok olacağı şeklinde görüş beyan etmektedir (Boyraz, 1998: 110). Bu görüş oldukça yüksek kültür seviyesini yakalamış olan toplumlar için bir bakıma doğru olabilir. Ancak grup kültürü 
bağlamında değerlendirildiğinde lakapların kolay kolay unutulamayacağı, eğitim seviyesi ne olursa olsun lakap takmanın devam edeceği görüşündeyiz. Bu görüşümüzü destekleyecek örnekler mevcuttur. Sağlık personeli, akademisyenler, öğrenciler vb. gruplar kendi aralarında birbirlerine veya başka gruplara kolaylıkla lakap taktıkları bilinmektedir. Meslek gruplarında lakapların kolay bir şekilde verilmesinde stereotiplerin etkisi belirgindir. Stereotip, önyargıları besleyen, koruyan önemli bir mekanizmadır. Belirli bir kategoriye ait kişilere ilişkin enformasyonların algılanmasındaki ve işlenmesindeki rolleri yanı sıra, gruplar hakkındaki beklentileri de etkilerler. Bir gruba ait özelliklerin tamamı olarak da tanımlanan stereotipler, dünyadaki olay ve insanların "kafamızdaki resimleri" olarak nitelendirilmektedir (Karataş, 2017: 133-135; Özdemir-Erdem, 2016).

Lakaplar çoğunlukla alt kültürlere ait ürün olarak kabul edilmektedir. Alt kültür olarak tanımlanan gruplar günümüzde halk kavramıyla karşılanmaktadır. En az ortak bir faktörü paylaşan herhangi bir insan grubuna halk denilmektedir (Dundes, 2006: 19). Halkın kendine has ağız özellikleri, kültürel unsurların tamamı sadece ait olduğu çevrede anlamlandırılabilmektedir. Halk dar bir bölgede yaşayan insan topluluğu olabildiği gibi geniş coğrafyalara yayılmış topluluklar veya herhangi bir meslek grubu da olabilmektedir.

Lakap, kişinin ailesi, anne-babası, soyu, mesleği, fiziki özellikleri, inancı, bir davranışı, memleketi, etnik kökeni gibi özelliklere bağlı olarak verildiğinden kişiyi tanımlamada kolaylıklar sağlamaktadır. Bu açıdan kişinin lakabı kişiliğini yansıtırken ad için ise böyle bir durum söz konusu değildir. Kişinin adı anne, baba veya büyükleri tarafından doğduğunda çeşitli dilek ve beklentiler düşünülerek verilmekte bu nedenle isim ve kişilik kimi zaman uyuşmakta kimi zaman da isim ve kişilik tamamen zıt olabilmektedir. Lakap ise doğrudan kişilik özelliklerini yansıttığından kişiyle kolay bir şekilde özdeşleşir ve çoğu zaman isimden ziyade kişiler lakaplarıyla tanınırlar (Kardaş, 2018: 4).

Bir kimseye kendisini seven, önemseyen biri tarafından da kendisini sevmeyen biri tarafından da bir lakap yakıştırılabilir. Bir lakabın yakıștırılması kadar bu lakabın toplulukça benimsenmesi de önemlidir. Ĕger topluluğun da onayından geçerse adlandırılan kişinin kimliğinin önemli bir öğesi olur. Başlangıçta sadece takan kişinin kullandığı lakap, toplum tarafından kabul görür ve benimsenirse zamanla yaygınlık kazanır ve grup kültürünün tüm üyeleri tarafından kullanılmaya başlanır. Lakap, zamanla öylesine işlerlik kazanır ki kişinin asıl adı kullanılmaz olur ve kişi sadece lakabıyla anılır. 
Araştırmalarımıza göre Zazaca lakaplar üzerine herhangi bir çalışma yapılmamıştır. Bu çalışma Türkçe lakaplar üzerine yapılan incelemelere doğrultusunda oluşturulmuştur. Türkçe lakaplar üzerine yapılan inceleme ve tasniflerin bazıları şunlardır:

Asiye Mevhibe Coşar, lakapları "1- Özel Lakaplar (kişilik özelliklerine göre verilen ve kişilerle özdeşleşmiş olan lakaplar), 2-Genel Lakaplar (kişilerin birtakım özelliklerine göre verilen, kalıcı isim özelliği olmayan, bir an için ve uygun düşen durumda herkes için kullanılabilen lakaplar)" olmak üzere iki ana kategoride incelemiştir (Coşar, 2003: 27-40). Nerin Köse, "1-Kişiye ait olan lakaplar, 2-Soya ait olan lakaplar" şeklinde (Köse, 2004: 269), Nevzat Özkan, "1-Kişinin kendinden kaynaklanan lakaplar, 2- Kişinin çevresinden kaynaklanan lakaplar, 3-Mensubiyete dayalı lakaplar, 4- Anlamı unutulmuş lakaplar" (Özkan, 2016: 180-189) olmak üzere dört başlıkta tasnif etmiştir. Ömer Akdağ ise "1-Uzun süre ve geniş bir topluluğu ifade eden lakaplar (Kara Tekeliler, Sarı Keçililer vb.). 2-Birinci gruptaki kadar yaygın değil ama mensup olduğu topluluk tarafindan kabul edilen lakaplar (Hacı Musalar, Hacı Gaffarlar vb.). 3-Kişiye mahsus lakaplar (Sürtük, Dana, Tilki vb.)" (Akdağ, 2015: 729) şeklinde üç kategoride sınıflandırmıştır.

Lakaplar tarih boyunca her kültürde kullanıldığı bilinmektedir. Ancak 2 Ocak 1935 tarihinde yürürlüğe giren 2525 sayılı soyadı kanunu ile lakapların yerini soyadlarının alması amaçlanmıştır. Kanunun 3. Maddesiyle lakabı hatırlatan rütbe ve memuriyet, așiret ve yabancı ork ve millet isimleriyle umumi edeplere uygun olmayan veya iğrenç ve gülünç olan soyadlarının kullanılması yasaklanmıştır. 26 Kasım 1935'te çıkarılan 2590 sayılı kanunun 1. maddesiyle "Ağa, Hacı, Hafız, Hoca, Molla, Efendi Bey, Beyefendi, Paşa, Hanım, Hanımefendi ve Hazretleri gibi lakap ve unvanlar kaldırılmıştır. Erkek ve kadın vatandaşlar, kanunun karşısında ve resmi belgelerde yalnız adlarıla anılırlar.” hükmü getirilmiştir (www.mevzuat.gov.tr erişim tarihi 22.04.2021).

Yukarıda bahsedilen bu kanunlarla her aile bir soyadı almış, ancak lakap kullanımı da devam etmiştir. Yakın zamanlara kadar Anadolu'nun pek çok köy, kasaba ve şehirlerinde kullanılan lakaplar üzerinde yapılan araştırmalar, lakap takma ve lakap kullanma alışkanlığımızın devam ettiğini göstermektedir.

\section{Emtağ Köyünde Kullanılan Lakaplar}

Emtağ, Bingöl ilinin Merkez ilçesine bağlı bir köydür. Köyün eski adı, 1550 yılı kayıtlarında Ermutak, 1928 yılı kayıtlarında ise Armutak şeklin- 
dedir. 1960 yılında adı Kırkağıl olarak değiştirilen köy, sakinlerinin başvurusu neticesinde 2015 yılında "Emtağ" adını aldı. Köyün Bingöl il merkezine uzaklığı 17 km'dir. Köyün 2019 yılının verilerine göre toplam nüfusu 774'tür (https://tr.wikipedia.org erişim tarihi 04.05.2021). Toplamda 4 mahallesi bulunmaktadır.

Bu çalışma Bingöl iline bağlı Emtağ köyünün dört mahallesinde lakaplar üzerine yapılan derleme çalışmasında elde edilen veriler neticesinde meydana getirilmiştir. Konuyla ilgili olarak Buni, Barakun, Le Hoşek, ve Le Saypil mahallesinde toplam 30 kaynak kişiyle görüşülmüştür. Tespiti yapılan lakapların Türkçe anlamları “Grûba Xebate ya Vateyî” sözlüğünden ve Abdurrahman Yılmaz tarafından hazırlanan "Zazaca-Türkçe Sözlük (Genç-Bingöl Yöresi)” adlı yüksek lisans çalışmasından yararlanılarak yazılmıştır. Söz konusu lakapların veriliş sebebi, kaynak kişilerin verdiği bilgiler doğrultusunda değerlendirilmiştir. Tespiti yapılan bazı lakapların örneği uygun görülmediği için verilmemiştir. Sadece lakabın anlam ve veriliş nedenine değinilmiştir. Bu tür lakapların kime verildiği herkes tarafından bilindiği için bizzat ismin karşısına lakabın yazılmasına gerek duyulmamıştır. Tespiti yapılan bazı lakapların tam manasıyla anlaşılması için çoğul eki topluluk eki veya yapım eki gibi ekler almışsa bu eklere değinilmiş ve bu kelimelerin dil bilimsel açıdan izahı yapılmıştır.

Çalışmamız Emtağ köyü ile sınırlı kalmıştır. Dolayısıyla lakaplar Emtağ köyünün ağız özelliklerini yansıtmaktadır. Civar köylerin kullandıkları lakaplar çalışmaya dâhil edilmemiştir. Çalışmada başvurulan kaynak şahıslar genellikle sülaleye dayalı lakapları söylemeye özen göstermişlerdir. Kişinin annesi, babası, dedesi veya sülalesinin adından hareketle verilen lakaplar sıkça kullanılmakla birlikte aşağılayıcı, hafife alma veya dalga amaçlı takılan lakaplar kaynak kişiler tarafından sakıncalı ve ayıp karşılanmıştır.

Derleme sahamızda tespiti yapılan bazı lakapların Zazaca halk türkülerinde geçtiği müşahede edilmiştir. Dolayısıyla lakaplar yazılı kültürde olduğu gibi halk bilgisi ürünlerinin birçoğunda da karşımıza çıkmaktadır. Örneğin çalışmamıza konu olan Emtağ köyünde söylenen Zazaca türkülerde sülaleye dayalı lakaplar sıkça kullanılmıştır. Aşağıda verilen bir halk türküsünde sülaleye dayalı lakaplar şu şekilde geçmektedir:

"İsmal Xêlefun qabloy telefun, Sılêmun Emık mar çay demık, Sılêmun Emêr save sımêr, Reşat Qeşun wen arqoşun, Eli Elun liyir qelun, Âdem Feti run çıkleti, Seid Seyfi meşke defi, Farday Musay korçyin resay, Ehmed Elıkun munen 
qolkun, Sıdqi Mallay gay Allay, Sabri Qeșun wen zebeşun, hay dıle yemman yemman esmere delale yemman..." (K.K. 37). ${ }^{1}$

Zazaca başka bir türküde ise kullanılan sülaleye dayalı bir lakap şu şekilde geçmektedir: "Hus Wasmunun ho cuward yen, day lero lero lero/Şiknen paşne solun o, pawe Fate xwi vinden..."2

Yukarıda zikredilen sülaleye dayalı lakapların izahatı sülale, anne ve baba bağlamında verilen mensubiyete dayalı lakaplar başlığı altında ele alınmıştır.

Lakaplar, kullanıldığı bölgenin dil özelliklerini, mizah anlayışını, gözlem gücünü, değer yargılarını ve dünya görüşünün anlaşılmasında önemli veriler sunmaktadır (Öztürk, 2016: 260). Bu açıdan bakıldığında Emtağ köyünde kullanılan lakaplarda ağız özellikleri, gözlem gücü ve mizahî anlayış göze çarpmaktadır.

Lakapların işlevleri "1-Medih yolu, 2-Tarif ve tanıtma, 3-Kötüleme ve hafife alma” olmak üzere üç şekilde ele alınmıştır (Türk Ansiklopedisi 1975: 455456, Coşar 2003: 27). Bunların dışında lakaplar, aynı ailedeki farklı nesiller arasında bağ kurma ve iletişimin belirli ölçüde de olsa devam etmesini sağlama bakımından "nesiller arasında iletişim/bağ kurma" işlevine de sahiptir. Özellikle aile büyüklerinin adının veya lakabının ailedeki bir kişiye ya da sülaleye lakap olarak verilmesiyle o bireyin birkaç neslinin de olsa hatırlanabilir olmasını sağlamaktadır (Atlı, 2017: 108).

Çalışmamızda, kaynak kişilerden alınan bilgilerden hareketle köy halkının sülale isimlerini de lakap olarak kabul ettiklerinden dolayı derleme sonucunda elde edilen lakaplar, 1-Kişisel/Ferdî Lakaplar, 2-Sülale Lakapları şeklinde iki ana başlıkta incelenmiştir. Elde edilen verilerden hareketle bu iki başlık da kendi içerisinde alt başlıklara ayrılarak mevcut malzeme incelenmiştir.

\subsection{Kişisel/Ferdi Lakaplar}

Kişisel/ferdi özelliğe göre verilen lakaplar derlenen malzemeye göre on üç başlık altında işlenmiştir. Derleme çalışmasında elde ettiğimiz lakaplar;

1 Türkünün Türkçe Çevirisi: Halefoğullarından İsmail telefon kablosuna benzer, Emine oğlu Süleyman bize çay demlesin, Ömer oğlu Süleyman saman küfesine benzer, Qeş sülalesinden Reşat tavşan yer, Alioğullarından Ali kargaların yavrularına benzer, Fethi oğlu Âdem sıvı yağa benzer, Seyfi oğlu Sait davulun derisine benzer, Musa'nın kızı Feride'nin armutları olgunlaştı, Alicikoğullarından Ahmet danalara benzer, Molla'nın oğlu Sıddık Allah'ın öküzüne benzer, Qeș sülalesinden Sabri karpuz yer, hay gönül hay gönül güzel esmerim yamman yamman...

2 (https://www.youtube.com/watch?v=yVL7qSNCXck 24.03.2021). 
kişilerin dış görünüşüne, fiziksel olarak hayvanlara, bitkilere, nesnelere, renklere, iş ve uğraşına, geldiği ikamet yerine, konuşma biçimine, zevk ve alışkanlıklarına, ikamet ettiği coğrafi mevkiinin şekline bağlı verilen lakaplar şeklinde başlıklar halinde ele alınarak incelenmiştir. Son olarak da sülale lakapları ana başlığı altında anne, baba ve sülaleye bağlı takılan lakaplar başlıkları altında mevcut malzeme değerlendirilmiştir.

\subsubsection{Diş Görünüşe Göre Verilen Lakaplar}

$\mathrm{Bu}$ başlık altında tespit edilen lakaplar kişinin dış görünüşü göz önünde bulundurularak verilen lakaplar oluşturmuştur. Yöre halkı kişinin ister dış görünüşü düzenli, tertipli olsun ister düzensiz, kirli ve üstüne başına dikkat etmemiş olsun lakap takmaktan geri durmamıştır. Tespitlerimize göre bu tür lakapların veriliş nedeni kişilerin üstünü başını temiz tutmamasından (junın, aspıcın, pılxın, mizın, gerın, çılmın, cıngıl), düzensiz giyinişinden dolayı (gelperı, raşayı), tertipli veya düzenli çalıştığından (qutti), köse veya kel olmasından (dı muy, keçel), saç kıran hastalığına uğradığı için (hevrıng), yaşlılar gibi göründüğü için (extıyar), iri yapılı olduğu için (qes), gibi hususlar göz önünde bulundurularak verildiği görülmektedir. Aşağıda bu lakapların veriliş sebebi maddeler halinde alfabetik olarak sıralanmıştır:

Aspıcın: Zazacada aspıc bit, aspıcın ise bitli demektir (Vate Çalışma Grubu, 2009: 36). -ın yapım eki Türkçedeki -lı, li yapım ekinine karşılık gelmekte olup bir şeyin kaynaklandığı malzemeyi yahut üretildiği malzemeyi veya nispeti ifade eder. Kişinin başına bit düştüğü için ve yıkanmadığı için aspıcın denmiş ve bu sıfat kişinin lakabı haline gelmiștir. Örnek olarak (Yusuf) "Wus aspıcın" verilebilir (K.K. 30).

Çılmın: Çılm Zazacada sümük demektir (V.Ç.G. 2009: 108) Çılmın ise sümüklü anlamında kullanılmıştır. -ın yapım eki Türkçedeki -lı, li yapım ekinine karşılık gelmekte olup bir şeyin kaynaklandığı malzemeyi yahut üretildiği malzemeyi veya nispeti ifade eder. Kişiye sürekli sümüğü aktığı için bu lakap verilmiştir. Örnek: (Osman) “Was çılmın” (K.K. 30).

Dı muy: Yöre Zazacasında dı iki, muy ise kıl demektir. Kelime iki kıl anlamında kullanılmıștır. Kişi seyrek sakallı veya köse olmasından dolayı dı muy lakabı verilmiştir. Örneğin: (Ahmet) “Ehm dı muy” (K.K. 63).

Extıyar: Zazacada yaşlı veya ihtiyar demektir (V.Ç.G. 2009: 165). Kelime Arapça kökenli olup iki şeyden birini diğerine tercih etmek, seçip ayırmak, üstün tutmak demektir. İhtiyar kelimesi Zazacaya extıyar şeklinde girip yaşlı insan anlamı kazanmıştır. Kişi hastalıktan dolayı cildi buruşuk genç olduğu 
halde yaşlılar gibi göründügü için bu lakap verilmiştir. Örnek olarak (Ferhat) "Fer extıyar" verilebilir (K.K. 32).

Gelperı: Bu sıfatın çalışmamızda kıstas olarak aldığımız V.Ç.G sözlüğünde herhangi bir karşılığı bulunmamıştır. Ancak "Zazaca-Türkçe Sözlük (Genç-Bingöl Yöresi)” adında bir yüksek lisans çalışmasında bu kelimenin karşılığı bakımsız, pejmürde anlamına geldiği tespit edilmiştir (Yılmaz, 2015: 53). Nitekim çalışma sahamızda da bu kelime tespit edilen anlamda kullanıldığ görülmüştür. Lakap olarak kişi düzgün giyinmediğinden ve üstünü başını tertipli tutmadığından takılmıştır. Örnek: (Aydın) “Ayd gelperı” (K.K. 32).

Gıngıl: Zazacada yumak veya iç içe girmiş saç demektir (Yılmaz, 2015: 55). Kişinin saçları kirli ve kıvırcık olduğu için bu lakap verilmiştir. Örnek: (İdris) "İd gıngıl" (K.K. 30)

Gerın: Zazacada ger uyuz, gerın ise uyuz hastalığına tutulmuş olan demektir (V.Ç.G. 2009: 186). Gerın kelimesindeki -ın yapım eki Türkçedeki -lı, li yapım ekinine karşılık gelmekte olup nispeti ifade eder. Kişi sürekli kirli dolaştığı için ve uyuz olduğundan bu lakap verilmiştir. Örnek: (Serdar) "Serd gerın” verilebilir (K.K. 30).

Hevrıng: Zazacada kırkma makası demektir (Yılmaz, 2015: 65). Yöre halkı bu kelimeyi saçları veya sakalı makasla kırkılmış gibi anlamında kullanmaktadır. Saçları ve sakalı saç kıran hastalığından dolayı yer yer dökülmüş olduğundan kişiye bu lakap verilmiştir. Örnek: (Mehmet) “Meh hevrıng” (K.K. 30).

Junın: Zazacada hastalıklı demektir (V.Ç.G. 2009: 296). Jun, salgın hastalık anlamında kullanılırken -ın yapım eki de Türkçedeki -lı, li yapım ekinine karşılık gelmekte olup hastalıklı anlamını vermektedir. Kişi temiz ve düzenli giyinmediği için ve uzun süre yıkanmadığı için bu lakap verilmiştir. Örnek: (Cihan) “Cikjunın” (K.K. 30).

Keçel: Zazacada kel demektir (V.Ç.G. 2009: 257). Saçları döküldüğü için bu lakap verilmiştir. Örnek olarak (Recep) “Rec kel” verilebilir (K.K. 40).

Mizın: Zazacada miz, sidik, mizın ise sidikli demektir (V.Ç.G. 2009: 260). -ın yapım eki Türkçedeki -lı, li yapım ekinine karşılık gelmektedir. Kişi genç denecek yaşta hala geceleri altına işediği için bu lakap verilmiştir. Örnek: (Bünyamin) "Bin mizın” (K.K. 23).

Pılxın: Zazacada sümük demektir (V.Ç.G. 2009: 382). Yukarıda da ifade edildiği gibi -ın yapım eki Türkçedeki -lı, li yapım ekinine karşılık gelmekte olup bir şeyin kaynaklandığı malzemeyi yahut üretildiği malzemeyi veya 
nispeti ifade eder. Bu lakap kişi temizliğine önem vermediği için takılmıştır. Örnek: (Eyüp) “Ek pılxın” (K.K. 32).

Qutti: Türkçesi kutu demektir (Yılmaz, 2015: 121). Kutu ismi Türkçeden Zazacaya qutti şeklinde geçmiştir. Kişiye her işinde düzenli ve tertipli olduğu için qutti diye lakap takılmıştır. Bu lakap kullanılırken isim verilmeden kullanılır ve herkes kimin kastedildiğini bilir (K.K. 24).

Qes: Zazacada kelimenin anlamı parça veya iri odun parçası demektir (Yılmaz, 2015: 116). Yöre halkı bu kelimeyi güçlü iri yapılı kimse için kullanmaktadır. Kişi iri yapılı ve güçlü olduğu için bu lakap verilmiştir. (Vahap) "Vah qes" (K.K. 30).

Qerpalın: Zazacda qerpal eskimiş, yıpranmış, deforme olmuş giysi demektir (V.Ç.G. 2009: 413). Qerpalın ise eski, yıpranmış, deforme olmuş giysi giyen kişi demektir. -ın yapım eki Türkçedeki -lı, li yapım ekinine karşılık gelmektedir. Kişi yırtık ve eski elbiseler giyindiği için bu lakap verilmiştir. Örnek: (Besile) "Besa qerpalın" (K.K. 40).

Raşayı: Sıfat, Zazacada anlamı dağınık, serpilmiş, silkinmiş demektir (Yılmaz, 2015: 123). Bu sıfat yöre Zazacasında dağınık olan ve tertipli giyinmeyenler için kullanılmaktadır. Kişi oturduğu yeri dağınık kullandığı için veya düzenli giyinmediği için raşayı lakabı ile lakaplanmıştır. Örnek: (Kazım) "Kaz raşayı" (K.K. 24).

\subsubsection{Herhangi Bir Nesne, Sebze ve Bitki ile Benzerlik İlgisi Kurularak Verilen Lakaplar}

Çalışma sahamızda kaynak kişi veya kişilerden derlediğimiz lakapların çoğunda bir benzerlik ilgisi görmek mümkündür. Genellikle türlü nesneler ile şekilsel olarak benzerlik ilgisi kurulmuş ve buna göre lakap yakıştırması yapıldığı gözlemlenmiştir. Kişi dış görünüşü itibariyle bir bitkiye, sebzeye veya eşyaya benzetilmiş ve buna göre lakap verildiği görülmüştür.

Kişi şişman olduğu için (xılık/xıl), kafasının küçük olmasından dolayı (Sare piyaz veya Sare kartol), büyük bir ağza sahip olduğu için tuluk veya değnek ile ilişki kurularak (fek aşir, fek uşir), çok zayıf veya buruşuk bir cilde sahip olmasından ötürü (pueste, mıcıqaye), başının küçük olmasından dolayı (sare kondez), kısa boylu tombul olduğu için ilkbaharda ağaçların tomurcuğuna benzetilerek (pındık), kötü koktuğu için (arwiync), bulaşık bezine nispet edilerek (girreşê fıraqan), kilime benzetilerek (erdiş pılas), gözlerinin iri olmasından ötürü (çım goz), kulaklarının büyük olmasından dolayı (gueş/ goş qax), parayı sevdiği için (cuzdun), her işte parmağı olduğundan (kueçıka 
nêşiti), düzgün ve tertipli giyinişinden dolayı (çiçegê wusar) bögürtlen dikenine benzetilerek (gurnıg) lakapları yakıştırılmıştır.

Görüldüğü üzere lakaplar nesneler arasında ilişki kurularak benzerlik yoluyla kullanılmıştır. Burada verilen lakapların anlam ve veriliş nedeni aşağıda alfabetik olarak maddeler halinde ele alınmıştır:

Arwiyenc: Zazacada bu kelime, içinde çökeleğin muhafaza edildiği torba anlamında kullanılır. Kişinin çökelek torbasına benzer yağlı bir vücudu ve kokusu olduğu için bu lakap verilmiştir. Bu lakap kullanılırken isim verilmeden kullanılır ve herkes kimin kastedildiğini bilir (K.K. 24).

Cuzdun: Zazacada cüzdan demektir (V.Ç.G. 2009: 97). Türkçeden Zazacaya bozularak cuzdun şeklinde geçmiş bir kelimedir. Kişi aşırı derecede cimri olduğundan ve parayı çok sevdiğinden dolayı cüzdan ile ilgi kurularak yani parayı kendinde tutan, cimrilik yapan anlamında bu lakap verilmiştir. Bu lakap kullanılırken isim verilmeden kullanılır ve herkes kimin kastedildiğini bilir. (K.K. 38).

Çiçegê wusar: Çiçeg, Zazacada çiçek “- $\hat{e}$ ” sesi ise Zazacada iki tamlama ekinden biri olup "- $\hat{e},-\hat{\imath}$ ” Türkçedeki “-(n)ın, -(n)in, -(n)un, -(n)ün, -im" tamlama eklerine karşılık gelmektedir. Wusar, ilkbahar demektir (V.Ç.G. 2009: 55109). İsim ilkbaharın çiçeği anlamını karşılamaktadır. Bu kişi tertipli düzgün giyindiği için adeta bir çiçeği andırdığından bu lakap verilmiştir. Bu lakap kullanılırken isim verilmeden kullanılır ve herkes kimin kastedildiğini bilir (K.K. 23).

Çım goz: Çım Zazacada göz, goz ise ceviz demektir (V.Ç.G. 2009: 89-48). Kişinin iri veya büyük gözlü olmasından dolayı gözü ceviz ile ilişkilendirilerek benzetme yoluyla çım goz lakabı yakıştırılmıştır. Örnek: (Cuma) “Cum çım goz" (K.K.16).

Erdiş pılas: Erdiş Zaza dilinde sakal anlamına gelmektedir (V.Ç.G. 2009: 181). Pılas ise kilim anlamında kullanılmıştır (V.Ç.G. 2009: 134). Kişinin sakalı uzun ve gür olmasından dolayı erdiş pılas lakabı ile anılmıştır. (Agit) "Eg erdiş pılas" (K.K. 63).

Fek uşir, fek aşir: Fek Zazacada ağız uşir değnek, asa, çubuk (uzun ağızlık); aşir ise tuluk demektir (V.Ç.G. 2009: 37-542). Yöre Zazacasında hem fek uşir hem de fek aşir tamlamaları kullanılmaktadır. Bu lakap kişinin ağzının büyüklük açısından normalin üstünde olmasından dolayı tuluk'a veya uzun ağızlı çubuğa benzetilerek fek uşir/fek aşir lakabı takılmıştır. Örnek: (Mahmut) “Meh fek aşir" (K.K. 30). 
Gırreşê firaqan: İsim tamlaması, bu tamlama Zazacada bulaşığın bezi anlamında kullanılmaktadır (V.Ç.G. 2009: 37). Girreş Zazacada bez, fıraq ise bulaşık demektir. Gırreşê kelimesindeki "- $\hat{e}$ ” sesi Türkçede kullanılan “-(n) ın, -(n)in, -(n)un, -(n)ün, -im” tamlama eklerine karşılık gelmektedir. Fıraqan kelimesindeki “-an" eki ise Zazacada çoğul yapan iki ekten "-i/y ve -an" biri olarak karşımıza çıkmaktadır. Kişinin sakalını bulaşık bezine benzetildiği için bu lakap verilmiştir. Bu lakap kullanılırken isim verilmeden kullanılır ve herkes kimin kastedildiğini bilir (K.K. 29).

Goş qax: Goş veya gueş, Zazacada kulak demektir (V.Ç.G. 2009: 195). Qax, ise kurutulmuş armut veya elma anlamlarını karşılamaktadır (V.Ç.G. 2009: 141). Kişinin kulakları dilimlenmiş kuru elma veya armutta benzetilerek bu lakap verilmiştir. Örnek: (Yadin) "Yad goş qax" (K.K. 29).

Gurnıg: Zazacada bögürtlen dikeni demektir (V.Ç.G. 2009: 141). İnsanlara rahat vermeyen bu kişi yapıştığı insanları kendisinden bezdiren bir karaktere sahip olduğu için gurnıg'a benzetilmiş ve bu lakap verilmiştir. Örnek: (Hasan) "Hes gurnig” (K.K. 29).

Kakıl veya dendık: Zazacada çekirdek, ceviz içi anlamlarında kullanılan bu kelimeler (V.Ç.G. 2009: 129) kişinin sarışın olması veya renk itibariyle ten renginin sarı olması benzerliğinden ilişki kurularak böyle bir lakap takılmıştır. Bu lakap kullanılırken isim verilmeden kullanılır ve herkes kimin kastedildiğini bilir (K.K. 30).

Kueçıka neşıti: Kueçık Zazaca sözlükte kaşık, neşıti ise yıkanmamış kirli anlamını karşılamaktadır (V.Ç.G. 2009: 124) Neşıti kelimesinin ilk hecesi Zazaca'da iki olumsuz eklerden "ne-, ni-“ biri olup kelimeye olumsuz bir ifade katmıştır. Bu ek Türkçede kullanılan “me, $m a$, sız, siz,” olumsuzluk eklerine karşılık gelip cümleye olumsuzluk anlamı katar. Yöre Zazacasında bu ifade, kişi olur olmaz her işe bulaştığından, iki kişi konuşurken konuşmaya dâhil olan ve burnunu her işe sokan yapısından dolayı kueçıka neşıti ye benzetilerek bu lakap verilmiştir. Bu lakap kullanılırken isim verilmeden kullanılır ve herkes kimin kastedildiğini bilir. (K.K. 28).

Mıcıqaye: Zazacada buruşuk anlamında kullanılır (V.Ç.G. 2009: 422). Kişi zayıf, kırılgan ve cildi buruşuk olmasından dolayı buruşmuş nesnelere benzetilmiş dolayısıyla bu lakap takılmıștır. Bu lakap kullanılırken isim verilmeden kullanılır ve herkes kimin kastedildiğini bilir (K.K. 30).

Pındık: Zazacada pınd, gonca, konca, tomurcuk anlamlarında kullanılır (V.Ç.G. 2009: 382). Pındık kelimesinin son hecesindeki “-lk" eki Türkçede 
kullanılan küçültme ekleri “-cik, -ce, -cek, -ceğiz, -imsi, -imtırak, -rek" eklerine karşılık gelmektedir. Bu küçültme ekleri Türkçede olduğu gibi Zazacada da küçüklük, sevgi, şefkat, azlık, yakınlık, acıma gibi anlamlar yükleyen ekler olarak ifade edilebilir. Kişinin küçük sevimli tombul ve çocuksu bir yüzü olduğu için tomurcuk ile benzerlik ilişkisinden hareketle pındık lakapı verilmiştir. Bu lakap da kullanılırken isim verilmeden kullanılır ve herkes kimin kastedildiğini bilir (K.K. 64).

Sare piyaz: Sare Zazacada baş/kafa, piyaz ise soğan demektir (V.Ç.G. 2009: 189). Kişinin başı küçük olmasından ötürü soğana benzetilmiş ve bu lakap verilmiştir. Yöre halkı kişinin başının küçük veya büyük olmasından dolayı bu lakapları sıkça kullanmışlardır. Örnek: (Siraç) “Sir sare piyaz” (K.K. 30).

Sare kartol: Sare Zazacada baş/kafa kartol ise patates demektir (V.Ç.G. 2009: 172). Kişinin başı küçük olmasından ötürü patatese benzetilmiş ve bu lakap verilmiştir Örnek: (Veysel) “Wes sare kartol” (K.K. 30).

Sare kondez: Zazacada sare, kafa; kondez ise yemek kepçesi demektir (V.Ç.G. 2009: 128). Kafası çalışmadığından ve yemek kepçesine benzerliğinden dolayı bu lakap verilmiştir. Örnek: (Kadir) “Kad sare kondez” (K.K. 24).

Sare dueq: Sare Zazacada kafa, dueq ise küçük tümsek demektir (V.Ç.G. 2009: 212). Zazacada kullanılan bu lakap şekilsiz veya yamuk kafa anlamlarını karşılamaktadır. Kişinin kafası şekilsiz veya yamuk olduğundan bu lakap verilmiştir. Örnek: (Fatih) "Fat sare dueq" (K.K. 24).

Viyerte: Zazacada geçmiş, kart, eskimiş, gençliği ve körpeliği kalmamış olan anlamlarında kullanılır (V.Ç.G. 2009: 563). Kişi çok zayıf veya hasta olduğu için eskimiş ve kullanılamaz nesnelere benzetilerek bu lakap verilmiştir. Örnek: (Enes) “En viyerte” (K.K. 33).

Xılık veya Xıl: Zazacada hem karın anlamına hem de xıl olarak isimlendirilen yuvarlak çömlek anlamında kullanılmıştır (V.Ç.G. 2009: 393). Kişi çok şişman olduğundan xıl veya xılıka benzetilmiş ve bu lakap verilmiştir. Örnek: (Ahmet) "Ehm xıl” (K.K. 30).

\subsubsection{Renkler ile İlgi Kurularak Verilen Lakaplar}

Bu başlık altında değerlendirilen lakaplar kişinin ten ve saç renginden yola çıkılarak verilen lakaplar oluşturmuştur. Yöre halkı bir kişinin sarışın, ten rengini siyah veya cildinin kırmızı olmasından dolayı renk ilişkisinden yola çıkılarak lakap yakıştırmasında bulunmuştur. Kişi sarışın olduğu için (zerık) kırmızı saç veya cildinin kırmızılığından dolayı (sur/surç) kara tene 
sahip olmasından (reş) lakapları ile anılmıştır. Yöre Zazacasında bu lakaplar sıkça kullanılmıştır. Bu dört lakabın anlamı ve veriliş nedeni şöyledir:

Reş: Reş, Kürtçe bir kelimedir. Anlamı ise kara/siyah demektir. Zazacada bu kelimenin karşılığı "qer"dir (V.Ç.G. 2009: 189). Ancak yöre Zazacasında bu kelime reş olarak kullanılmaktadır. Yöre halkı bu kelimeyi kara tenli kişiler için kullanmaktadır. Kişinin ten renginin kara olmasından dolayı bu lakap verilmiştir. Örnek: (Ayhan) “Ayd reş” (K.K. 30).

Sur, Surç: Zazacada sözlükte kırmızı anlamında kullanılmıştır (V.Ç.G. 2009: 482). Ten rengi, saç rengi veya cildinin kırmızılığından dolayı kırmızı renk ile ilgi kurularak sur/surç lakapı verilmiştir. (Salih) "Sal sur” (K.K. 27).

Sitqer: Zazacada qer kara, sitqer ise kapkara demektir. Çalışma sahamızda bu kelimenin lakap olarak kullanıldığı ve anlamının kapkara olduğu tespit edilmiştir. "sit-" eki Zazacada "qer" kelimesiyle birleştirilerek Türkçede pekiştirme ekleri olan "sim-siyah, yem-yeşil, mas-mavi, sap-sarı vb."ne karşılık gelebileceği düşünülmektedir. Bu lakap kişinin ten renginin kapkara olmasından dolayı pekiştirilerek sitqer lakabıyla lakaplanmıştır. (Yusuf) "Wus sitqer" (K.K. 24).

Zerık: Zazacada bu kelime sarılık, şap hastalığı (V.Ç.G. 2009: 612), anlamında kullanılmakla birlikte kelime aynı zamanda sarışın için de kullanılmaktadır. Ayrıca bu kelime "Zerıki şondi" tamlamasında olduğu üzere akşamüzeri, ikindi gölgesi, alacakaranlık anlamında da ifade edildiği görülmüştür. Kişinin sarışın olması ve sararan teninden dolayı renk itibariyle ilgi kurularak zerık lakapı takılmıştır. Örnek: (Kazım) "Kaz zerık” (K.K.16).

\subsubsection{Hayvanlara Benzetilerek Verilen Lakaplar}

Çalışma sahamızda derlediğimiz lakapların çoğu hayvan benzetmeleri ile ilgili olduğu tespit edilmiştir. Ancak kaynak şahıslar bu lakapları söylerken çekingen davranmışlardır. Zira bu lakaplar toplum içinde rencide edici anlamlar taşıdığı için pek dillendirilmediği müşahede edilmiştir. Söylenen birçok lakap kaynak kişiler tarafından kayıt altına alınmasına izin verilmediği için burada ele alınamamıștır. Dolayısıyla kaynak kişiler tarafından izin verildiği ölçüde derlenen lakapları incelediğimizde şu durumla karşılaşmaktayız: Yöre Zazacasında kişinin çok kıllı olmasından dolayı (bıze), şişman olduğu için ( munga), kuvvetli, uzun boylu ve iri yapılı olduğu için (her Mısır), kurnaz olduğu için (tirmar), dişleri ve kulaklarının büyüklüğünden dolayı (muş), zayıf olduğu için (malık), dış görünüşünün çirkinliğinden dolayı (keftar), sakar olduğu için (kerge kor), Kertenkeleye benzetildiğinden (kelte), 
Yine kurnazlığından dolayı (luw ve marî bın şimel), aktifliğinden dolayı (cun kutık) guguk kuşuna benzetildiği için (dik sılêmun) gibi lakapların kullanıldığı tespit edilmiştir. Aşağıda bu lakapların anlamı ve veriliş nedeni alfabetik olarak maddeler halinde ele alınmıştır:

Bıze: Zazaca sözlükte keçi anlamında kullanılmıştır (V.Ç.G. 2009: 73). Kişi aşırı derecede kıllı olduğundan keçi anlamında bıze lakabı verilmiştir. Örnek: (Şükrü) “Şuk bıze” (K.K. 30).

Cun kutık: Cun Zazaca sözlükte "gan" şeklinde geçmekle birlikte can anlamını karşılamaktadır. Kutık ise köpek demektir (V.Ç.G. 2009: 47-138). Yöre Zazacasında "gan" kelimesi " $g / c, a / u$ " harf değişimine uğrayarak cun şeklini almıştır. Kelimenin anlamı köpek ruhlu veya köpek canlı demektir. Halk bu lakabı aktif kimseler için kullanmaktadır. Kişi aktifliğinden dolayı her türlü işin içinde olduğu için hiçbir şeyden geri durmadığından bu lakap verilmiştir. Bu lakap kullanılırken isim verilmeden kullanılır ve herkes kimin kastedildiğini bilir (K.K. 32).

Dik Sılêmun: Bu isim guguk kuşu için kullanılmaktadır. Guguk kuşu Zazacada pepuk, gugu, ve dik Sılêmun olarak üç ayrı isimde ifade edilmektedir (V.Ç.G. 2009: 372). Zazacada dik horoz demektir Sılêmun ise Süleyman isminden bozulma özel isimdir. Yöre Zazacasında guguk kuşu için dik Sılêmun ifadesi kullanılmakla birlikte lakap olarak da kişi dış görünüşü itibariyle bu kuşa benzetilerek lakap yakıştırması yapılmıştır. Bu lakap kullanılırken isim verilmeden kullanılır ve herkes kimin kastedildiğini bilir. (K.K. 37).

Her Mısır: Zazacada Mısır'ın eşeği anlamında kullanılmıştır. Her, Zazacada eşek demektir (V.Ç.G. 2009: 76). Mısır ise ülke olarak bilinen Mısır ülkesi anlamında ifade edilmiştir. Eskiden hayvanların yaşı, cinsi/türü ve çeşidine göre değeri belirlenirdi. Yöre Zazacasında bu tür hayvanların cinsinin kaliteli, kuvvetinin yerinde oluşu ve büyüklük açısından neredeyse bir at boyutunda olmasından dolayı büyük ve kuvvetli eșek, Mısır'dan gelmiş kadar kaliteli eşek anlamında "her Mısır" ifadesi kullanılmıştır. Kişi uzun boylu ve iri yapılı olduğu için her Mısır lakabıyla anılmıştır. Bu lakap kullanılırken isim verilmeden kullanılır ve herkes kimin kastedildiğini bilir. (K.K. 37).

Keftar: Zazacada sırtlan demektir (V.Ç.G. 2009: 258). Kişi çirkin görünüşü ve düzensiz giyinişinden dolayı keftar lakabıyla anılmıştır. Bu lakap kullanılırken isim verilmeden kullanılır ve herkes kimin kastedildiğini bilir. (K.K. 30). 
Kerge kor: Kerge Zazacada tavuk, kor ise kör demektir (V.Ç.G. 2009: 205138). Yöre Zazacasında halk bu sıfat tamlamasını sakar anlamında kullanmıştır. Kişi sakar olduğundan kerge kora benzetilerek bu lakap verilmiştir. Bu lakap kullanılırken isim verilmeden kullanılır ve herkes kimin kastedildiğini bilir. (K.K. 24).

Kelte: Bu kelimenin Zazaca sözlükte bir karşılığı bulunmamıştır. Yöre halkı bu kelimeyi kertenkele anlamında kullanmaktadır (K.K. 32). Kelimenin Türkçede birçok anlama geldiği tespit edilmiştir. TDK'de kelte kelimesi "1-Tarikatten olmayan, yabancı. 2-Sanatında ya da işinde ilerleyemeyen. 3-Küçük, yaşlı palamut ağacı. 4-Kertenkeleden daha küçük sirtındaki pullar sert ve az olan bir sürüngen. 5-Küfe, sapsız sepet. 6-Verimsiz toprak. 7-Kısa." (https:// sozluk.gov.tr erişim tarihi: 15.05.2021) gibi anlamlarında kullanılmıştır. Yukarıda da görüldüğü üzere kelime, Türkçede kertenkele anlamında yörenin Zazacasına kelte şeklinde bozularak girmiş olabileceği düşünülmektedir. Zira kertenkelenin Zazaca sözlüklerde kullanımı kelte değil "marula"dır (V.Ç.G. 2009: 306). Ancak bu yörenin Zazacasına kelime kelte olarak geçmiş ve kertenkele anlamında kullanılmıștır. Kelte kelimesi bazen "kelteyê miyerdon" tamlamasında da görüldüğü üzere, yiğitlerin seçkini gibi bir anlamda da kullanılmıştır. Ancak yöre Zazacasında bu anlamda pek kullanılmadığı görülmüştür. Dolayısıyla kişi görünüş itibariyle kertenkeleye benzetilerek bu lakap verilmiştir. Örnek: (Enes) “En kelte” (K.K. 32).

Luw: Zazaca sözlükte tilki anlamında kullanılmıştır (V.Ç.G. 2009: 209). Kişi hem dış görünüşü itibariyle tilkiye benzetildiği için hem de kurnazlık yaptığı için bu lakap ile adlandırılmıştır. Örnek olarak (Yunus) "Yun Iuw" gösterilebilir (K.K. 24).

Munga: Zazacada inek anlamına gelmektedir (V.Ç.G. 2009: 331). Kişi çok şişman olduğundan bu lakap verilmiştir. Örnek: (Mazlum) "Maz munga" (K.K. 27).

Muş: Zazaca sözlükte köstebek anlamında kullanılmıştır (V.Ç.G. 2009: 215). Bu kişi hem kulaklarının ve dişlerinin büyük oluşu hem de sır tutamayan yapısından dolayı muşa benzetilmiş ve bu lakapla anılmıştır. Örnek: (Yadin) "Yad muş" (K.K. 28).

Malık: Zazacada solucan, yersolucanı, bağırsak solucanı demektir (V.Ç.G. 2009: 304). Bu kişi hasta ve zayıf olduğundan çabaladığı halde kilo alamadığı için ince ve zayıf anlamında solucana benzetilerek malık lakabı verilmiştir. Örnek: (Bünyamin) "Bin malık” (K.K. 32). 
Marî bın şimel: Zazacada mar, yılan, bın, alt, şimel ise orak ile biçilen henüz istiflenmemiş buğday yığını demektir. " $-\hat{\imath}$ ” sesi, Zazacada iki tamlama ekinden biri olup "-ê, - $\hat{\imath}$ ” Türkçedeki "-(n)ın, -(n)in, -(n)un, -(n)ün, -im" tamlama eklerine karşılık gelmekte olup Zazacada “-deki” anlamını ifade eder. Bu tamlama buğday yığını altındaki yılan anlamına gelmektedir. Yöre halkı bu kelimeyi kurnazlık anlamında kullanmıştır. Bu kişi çok kurnaz olduğu için bu lakap verilmiştir. Bu lakap kullanılırken isim verilmeden kullanılır ve herkes kimin kastedildiğini bilir. (K.K. 24).

Tirmar: Zazacada tir, oklava mar ise yılan demektir. Yöre Zazacasında bu kelime birleştirilerek anlam bozulmasına uğramış dişi yılan anlamını kazanmıştır. Bu kelime lakap olarak kullanıldığında ise yine anlam kaybına uğrayarak fitne ve fesat anlamına gelecek şekilde kullanıldığı görülmüştür. Kişi türlü fitne fesat kendisinde barındırdığı için tirmar lakabı ile anılmıştır. Bu lakap kullanılırken isim verilmeden kullanılır ve herkes kimin kastedildiğini bilir. (K.K. 32).

\subsubsection{Fiziki Engele veya Kusura Göre Verilen Lakaplar}

İnsanlık tarihi boyunca hemen hemen her bölgede insanların engel durumlarına göre lakaplar yakıştırılmıştır. Bu bazen devlet başkanları için de kullanılmıştır. Bunun en meşhur örneği Timur Leng'dir. Sosyal hayatta sıklıkla karşılanan bu durumdan kaynaklı lakaplar da Zazacada yoğunlukla karşımıza çıkmaktadır. Nitekim araştırma sahamız olan Emtağ'da da bu lakapların örneğine rastlanmıştır. Kişilerin doğuştan gelen ya da daha sonradan yaşanılan bir kaza sonucunda herhangi bir fiziksel engelinin kalması nedeniyle bu engele bağlı olarak verilen lakaplar bu başlık altında değerlendirilmiştir.

Kişiye bir iş kazası sonucunda kopan parmağından dolayı (quet/qot), topal olduğu için (leng), paytak yürüdüğü için (palvızd), kör olduğu için (kor), yamuk ağzından dolayı (çot), sağır olduğu için (ker), kambur olduğu için (kuz) konuşamadığı için (lal), zekâ geriliğinden dolayı (sefyek) deli olduğu için (gej), şaşı olduğu için (şaş) denildiği görülmüştür. Burada verilen lakapların anlam ve veriliş nedeni aşağıda alfabetik olarak maddeler halinde ele alınmıştır:

Çot: Sıfat, Zazacada yamuk, eğri demektir (Yılmaz, 2015: 32). Geçirdiği bir hastalıktan dolayı çenesi hafif yamuk kalmıştır dolayısıyla çot lakabı ile anılmıştır. Örnek olarak (Mehmet) “Meh çot” verilebilir. (K.K. 38). 
Gej: Sıfat, Zazacada deli demektir (V.Ç.G. 2009: 60). Doğuştan zekâ geriliği ile dünyaya geldiği için bu lakap ile anılmıştır. Örnek olarak (Şahin) "Şak gej" verilebilir (K.K. 32).

$K_{e r}{ }^{3}$ : Sıfat, Zazacada sağır anlamında kullanılmıştır (Yılmaz, 2015: 76). Doğuştan sağır oldukları için bu lakap verilmiştir. Örnek olarak (İsmail ve Hüseyin) "İs ker, Hus ker" verilebilir (K.K. 38).

Kuz: Sıfat, Zazacada kambur demektir (V.Ç.G. 2009: 287). Bu kişi doğuştan kambur olduğu için bu lakap takılmıştır. Örnek olarak (Veli) "Vel kuz" verilebilir. (K.K. 38).

Kor: Sıfat, Zazacada kör demektir (V.Ç.G. 2009: 138). Sonradan geçirdiği bir hastalıktan ötürü bir gözü görmediği için bu lakap verilmiştir. Örnek olarak (Ferhat) "Fer kor" verilebilir (K.K. 38).

Lal: İsim, Zazacada dilsiz demektir. (Yılmaz, 2015: 83). Kişi doğuştan dilsiz olduğu için lal lakabı ile adlandırılmıştır. Örnek olarak (Talip) "Tal lal" verilebilir (K.K. 32).

Leng: Sıfat, Zazaca topal demektir (V.Ç.G. 2009: 210). Kişi doğuştan bir ayağının topal olmasından dolayı bu lakap verilmiştir. Örnek olarak (Osman) “Was leng” verilebilir (K.K. 38).

Palvızd: Sıfat, Zazacada paytak yürüyen demektir (Yılmaz, 2015: 104). Yöre Zazacasında bu kelime paytak yürüyen kişiler için kullanılmaktadır. Kişi doğuştan hafif fiziksel engelli olduğundan yürürken düzgün yürüyemediği için bu lakap verilmiştir. Örnek olarak (Mehmet) "Meh palvızd" verilebilir (K.K. 32).

Quet/Qot: İsim, Zazacada kütük, kesik, yarım anlamlarında kullanılmaktadır (V.Ç.G. 2009: 144). Lakap burada kesik anlamında kullanılmıştır. Çerkez bir kaza sonucu sol elinin orta parmağını kaybettiği için kesik Çerkez anlamında "Cerk quet/qot" lakabıyla anılmıştır (K.K. 63).

Sefyek: Zazacada saf, temiz kalpli, gariban, zekâ seviyesi düşük anlamlarını karşılamaktadır (Yılmaz, 2015: 131). Bu sıfat kişinin saf, temiz kalpli ve gariban olmasından ötürü lakap olarak uygun görüldüğü tespit edilmiştir. Örnek olarak (Aydın) "Ayd sefyek" lakabı verilebilir (K.K. 30).

Şaş: Sıfat, Zazaca şaşı demektir (Yılmaz, 2015: 31). Kişi sonradan geçirdiği bir hastalıktan dolayı şaşı kalmış ve bu onun lakabı olmuştur. Örnek olarak: (İsa) "İs şaş" verilebilir (K.K. 28).

3 Buradaki "ker" sağır anlamında kullanılmıştır. 


\subsubsection{Geldiği İkamet Yerine Bağlı Olarak Verilen Lakaplar}

Çalışma sahamızda tespiti yapılan lakapların bazıları kişinin önceden ikamet ettiği veya doğduğu yerin ismine göre verildiği görülmüștür. Tarihte de bu gibi lakapların örneği oldukça fazladır. Bunun en güzel örnekleri Şems-i Tebrîzî, Sa'dî-i Şirâzî, Sadreddîn-i Konevî, İbrâhim Hakkı Erzurûmî vb. isimlerdir. Sosyal hayatta sıklıkla karşılanan bu durumdan kaynaklı lakaplar Zazacada da karşımıza çıkmaktadır. Nitekim araştırma sahamız olan Emtağ'da da bu lakapların örneğine rastlanmıştır.

Tespit edilen kişiler Sarıcan, Palu ve Baran'da daha önce ikamet ettiği yahut doğduğu için (Sarconuc, Paluıc, Barunıc) lakapları takılmıștır.

Sarconıc: Sarıcan, Elazığ ilinin Karakoçan ilçesine bağlı bir beldedir. Zazacada " $-I C,-I Z$, - $-l j$ " yapım ekleri Türkçedeki "-ll, li" yapım eklerine karşılık gelmekte olup nispeti ifade eder. Dolayısıyla kelime Sarıcanlı anlamında ifade edilir. Bu kişi Sarıcan beldesinde doğup büyümüş gelin olarak Emtağ köyüne gelmiştir. Dolayısıyla daha önce mensup olduğu yerin adıyla anılmaya başlamıștır. Örnek: (Arife) “Sarconıc” (K.K. 32).

Paluıc: Palu, Elazığ'ın bir ilçesidir. "- $I c$ ” Zazacada yapım ekidir. Dolayısıyla kelime Palulu anlamını ifade eder. Palu'da doğup büyüyen bu kişi Emtağ’a gelin olarak gelmiştir. Daha önce yaşadığı yere mensubiyetinden dolayı bu lakap verilmiştir. Örnek: (Naz) "Paluıc" (K.K. 32).

Barunıc: Baran, Bingöl'e bağlı Gökçekanat köyünün bir mezrasıdır. Yukarıda da ifade edildiği üzere " $-I c$ " yapım ekinden dolayı kelime Baranlı anlamına gelmektedir. Emtağ’a gelin gelen bu kişi daha önce yaşadığı yerin ismiyle anılmış ve bu lakap ile tanınmıștır. Örnek: (Halise) “Barunıc” (K.K. 32).

\subsection{8. İkamet Ettiği Coğrafi Yerin Şekline Göre Verilen Lakaplar}

Çalışma sahamızda kişinin oturduğu coğrafi yerin şekline bağlı verilen lakaplar pek kullanılmamakla birlikte tespiti yapılan bir lakap aşağıda veriliş nedeniyle birlikte verilmiştir.

Derı: İsim, Zazacada dere demektir (V.Ç.G. 2009: 61). Dere kelimesi Türkçeden Zazacaya derı şeklinde bozularak geçmiştir. Bu kişinin evi derede olduğu için (Cuma) "Cum derı" demişler ve lakap olarak kalmıştır (K.K. 28).

\subsubsection{Konuşma Şekline Göre Verilen Lakaplar}

Çalışma sahamızda tespiti yapılan lakapların bir kısmı da konuşma şekline bağlı olarak takılan lakaplardır. Yöre halkı kişi konuşurken anlamlı veya 
anlamsız, sürekli konuşma arasında tekrar ettiği kelimeden hareketle lakaplanmıştır. Bu lakaplar kullanılırken kişinin adı zikredilmeden sadece lakabı ifade edilir. Dolaysıyla kişi bu lakabıyla tanınır ve kim olduğu herkes tarafından bilinir. Tespiti yapılan bu kişiler konuşurken laf arasında sürekli (xalo, yani, bıra, xora, aferem, edo), kendisinin inandırmak için (hewt bar kitap, Kelum Qedim) gibi kelimeler tekrar ettiği için bu lakaplarla anılmış ve tanınmışlardır. Așağıda bu lakapların anlam ve veriliş nedeni maddeler halinde verilmiştir:

Aferem: Ünlem, Farsça kökenlidir. Kelime Türkçe sözlükte "övme, takdir, beğenme vb. duyguları belirtmek için söylenen söz" șeklinde geçmektedir (https://sozluk.gov.tr erişim tarihi: 04.05.2021). Türkçeden Zazacaya aferem şeklinde geçmiş Türkçede de olduğu gibi takdir ve beğenme anlamlarını ifade eder. Bu kişi birini dinlerken iki de bir aferem dediği için bu lakap takılmıştır (K.K. 29).

Bıra: İsim, Zazacada erkek kardeş demektir (V.Ç.G. 2009: 121). Kişi konuşurken laf arasında çok fazla bıra demesinden dolayı bu lakap ile anılmıştır (K.K. 29).

Edo: Lakap olarak anlamsız bir kelime olmakla birlikte Abdurrahman isminin Zazacadaki ifade şekli anlamı da mevcuttur. Kişi konuşurken laf arasında ikide bir edo dediği için bu lakap verilmiştir (K.K. 38).

Hewt bar kitab: Tamlama, Zazacada yedi yük kitap anlamına gelmektedir. Zazacada hewt, yedi; bar, yük demektir. Yöre Zazacasında kitap denilince akla Kur’an-ı Kerim gelir. Dolayısıyla kişi inandırıcılığını pekiştirmek için söylediği her cümlenin ardından vurgulama yöntemiyle kitap veya bir kat daha pekiştirerek hewt bar kitap dediği için bu onun lakabı haline gelmiştir (K.K. 28).

Kelum qedim: Arapça tamlama, Zazacada Kur'anı Kerim, Kadim kelam demektir (Yılmaz, 2015: 76). Bu kişi de her konuşmaya başladığında ilk önce kelum qedim diyerek söze başladığı için bu tamlama onun lakabı haline gelmiştir (K.K. 28).

Yani: Bağlaçtır. TDK'ye göre ya'ni kelimesi köken bakımından Arapça bir kelimedir. "demek oluyor ki, sözün kısasl, doğrusu" anlamlarında kullanılır (https://sozluk.gov.tr erişim tarihi: 04.05.2021). Bu bağlaç Türkçede kullanıldığı gibi Zazacada da kullanılmaktadır. Zazacada da ayni anlamı ifade eder. Kişi konuşma sırasında çok fazla yani bağlacı kullandığı için lakabı yani olarak kalmıştır (K.K. 28). 
Xalo: Xal, Zazaca sözlükte dayı demektir, xalo ise hitap halidir (V.Ç.G. 2009: 59). Kişi konuşurken konuşma arasında xalo kelimesini çok tekrar ettiği için xalo lakabıyla anılmıştır (K.K. 28).

Xora: Zarftır, Zazaca sözlükte “zaten, esasen" anlamında kullanılmıştır (V.Ç.G. 2009: 595). Yöre Zazacasında da bu kelime zaten anlamında kullanılmaktadır. Kişi konuşurken ikide bir xora dediği için xora demişler ve onun lakabı olarak kalmıştır (K.K. 38).

\subsubsection{Karakteristik Özelliklere Göre Verilen Lakaplar}

Lakapların büyük bir kısmı kişinin karakteristik özelliklerini oluşturan alışkanlıklarına, tavır ve davranışlarına bağlı olarak verilmektedir. Derlediğimiz lakapların genel olarak kişinin ani ve dengesiz hareketlerine (tovtovuk), sürekli göz kırpmasına (taptapık), gece dolaşmasına (mierdê şew), çok konuşmasına (fek fazıl), vakitli vakitsiz her ortamda yemek yemesine (çıllek), yalan söylemesine (torê zurun), tembel olmasına (pıntin), çok gezmesine (kuçe gezun), yaramaz olmasına (lir nefrêt), çabuk sinirlenmesine (pız), başıboş veya aylak gezmesine (beredayı, zıngur), fuzuli konuştuğu için (fek fazıl), kafası çalışmadığı için (qaf kundır) denildiği tespit edilmiştir. Aşağıda bu başlık altında tespit edilen lakapların anlam ve veriliş nedeni sırasıyla verilmiştir:

Beredayı: Sıfat, Zazacada çalışmayan, başıboş gezen demektir (V.Ç.G. 2009: 57). Kişi başıboş gezdiğinden iş güçle ilgilenmediği için bu lakap verilmiştir (K.K. 68).

Çıllek: Sıfat, Zazacada açgözlü demektir. Yöre Zazacasında bu kelime pisboğaz veya açgözlü anlamında kullanılmaktadır. Doymak bilmeyen olur olmaz yerde yemek yiyen bu kişiye çıllek denilmiş ve lakap olarak kalmıştır (K.K. 23).

Fek fazıl: Fek, Zazacada ağız demektir (V.Ç.G. 2009: 172). Fazıl ise boş veya fuzuli konuşmak anlamında kullanılmaktadır. Fek fazıl, ağzı boş laf yapan demektir. Kişi fuzuli konuştuğu için ağzı boş laf eden anlamında bu lakap verilmiştir (K.K. 28).

Kuçe gezun: Zazacada kuçe sokak demektir (V.Ç.G. 2009: 189). Gezun ise gezen anlamında kullanılmaktadır. Yöre Zazacasında tamlama başıboş serserilik anlamında ifade edilmektedir. Bu kişi sürekli başıboş gezdiği için kuçe gezun lakabı takılmıştır (K.K. 29).

Lir Nefrêt: Tamlama, Zazacada lir, yavru demektir (Yılmaz, 2015: 85). Nefret ise tiksinme, tiksinti duygularını ifade eder. Lir nefrêt ise nefretten doğma 
demektir. Kişi yaramaz, aktif ve enerji dolu olduğu için insanların nefretine maruz kaldığından bu lakap verilmiştir (K.K. 28).

Miyerdê şew: Sıfat, Miyerdı Zazacada koca, şew ise gece demektir (Yılmaz, 2015: 94-139). Ancak miyerdı kelimesi aynı zamanda hem yiğit hem de adam anlamında kullanılmaktadır. Burada ise gece adamı, geceleri dolaşan kişi anlamında kullanılmıştır. Sebebi de mitolojidir. Kırlu veya miyerdê şew biraz da kâbus anlamında kullanılmaktadır. Geceleri olumsuz işler peşinde gezen kişi anlamı da mevcuttur. Kişi geceleri görünüp daha sonra ortalıktan kaybolunca kişiye gecelerin adamı anlamında miyerdê şew lakabı takılmıştır (K.K. 57).

Pıntin: Sıfat, Zazacada cimri demektir (V.Ç.G. 2009: 383). Bu kişi aşırı cimri olduğu için pıntin denmiş ve bu kelime onun lakabı haline gelmiştir (K.K. 24).

Pız: Sıfat, Zazacada kelimeni manası çabuk sinirlenen anlamındadır (V.Ç.G. 2009: 392). Bu kişiye çabuk sinirlenen yapısından dolayı pız lakabı takılmıştır (K.K. 44).

Qaf kundır: Zazacada qaf sert kabuk veya bir tür kabak çeşidi demektir (Yılmaz, 2015: 114). Kundır ise Kürtçe kabak demektir. Kelime Kürtçeden alınıp kullanılmıștır. Yöre halkı bu tamlamayı boş kabak anlamında ifade etmiştir. Kişiye bir şeyin defalarca anlatılmasına rağmen anlamıyorsa özellikle ders çalışırken ezberi zayıfsa bu lakap ile lakaplandırılır (K.K.28).

Taptapık: Sıfat, Zazacada kelimenin anlamı oyuncak tabancadır. Ancak yöre Zazacasında tapık kelimesi göz kapağı anlamında da kullanılmaktadır. Taptapık ise oyuncak tabanca anlamı olmakla birlikte göz kırpma halini de ifade eder. Lakabın veriliş sebebi kişi sürekli gözlerini kırptığı için taptapık denilmiş ve lakap olarak kalmıştır (K.K. 38).

Tovtovık: Sıfat, Zazaca sözlükte herhangi bir karşılığı yoktur. Yöre halkı bu kelimeyi sağı solu belli olmayan ve dengesiz davranan kişi için kullanmış ve lakap halini almıştır (K.K. 31).

Torê zurun: Tamlama, tore Zazacada torba zur ise yalan demektir. Zurun kelimesinin son eki “-un” Zazacada çoğul ekidir. Dolayısıyla kelime yalanlar anlamını ifade eder. Torê zurun, yalanlar torbası anlamını karşılamaktadır. Bu kişi yalan söylediği için torê zurun denmiş ve lakap halini almıştır (K.K. 37).

Zıngur: Sıfat, kelime Zazacada serseri, başıboş anlamlarına gelmektedir (Yılmaz, 2015: 175). Bu kişiye başıboş ve serseriliğinden dolayı zıngur denilmiş ve onun lakabı olmuştur (K.K. 28). 


\subsubsection{1. İş ve Uğraşa Göre Verilen Lakaplar}

Kişilerin mesleğine ya da iş ve uğraşına bağlı olarak verilen lakaplar vardır. Bu tür lakaplara Anadolu'nun her şehrinde, kasabasında yahut köyünde rastlamak mümkündür. Ancak çalışma sahamızda iş ve uğraşa bağlı olarak takılan lakapların pek kullanılmadığı görülmekle birlikte kişinin kaçak sigara satmasına (Ehm Kaçax), yurtdışı seyahatlerinden dolayı (Tucar Halep), çobanlık yapmasına (Ez gawun) denildiği tespit edilmiştir. Tespit ettiğimiz bu üç lakabın anlam ve veriliş nedeni aşağıda maddeler halinde verilmiştir:

Gawun: Zazacada çoban demektir (Yılmaz, 2015: 165). Mesleği çobanlık olduğu için bu lakap verilmiştir (Aziz) "Ez gawun" (K.K. 31).

Kaçax: Zazacada kaçak demek olup Türkçeden Zazacaya bir harf değişikliğine uğrayarak kaçax şeklinde girmiştir. Bu kişi kaçak sigara sattığı için bu lakap takılmıştır. Örnek: (Ahmet) "Ehm kaçax" (K.K. 28).

Tucar Halep: Halep tüccarı demektir. Bu kişi İran'da baklava dükkânı açmıştır. Yılda en az bir iki defa İran, Irak gibi yerlere bal götürüp satmaktadır. Dolayısıyla kişiye "Tucar Halep" lakabı verilmiștir (K.K. 63).

\subsubsection{Meşhur Kişilere Benzerliği ya da Hayranlığına Bağlı Olarak Verilen Lakaplar}

Lakap verme geleneğinde kiş̧ilerin meşhur veya ünlü kişilere benzerliğinden ya da hayranlığından dolayı lakap verilebilmektedir. Kişi bir dizi ya da filim karakterine benzerliğinden veya hayranlık duymasından meydana gelen tavır ve davranış şekli lakap takılmasına olanak sağlamıştır. Ancak bu başlık altında tespit edilen lakaplar oldukça azdır. Bu gibi lakaplar yöre halkı tarafından pek tercih edilen lakaplar olmadığı müşahede edilmiştir. Takılan lakaplar da genellikle Türkçe lakaplar olduğu için çalışmamızın dışında tutulmakla birlikte ilerdeki çalışmalara katkı sağlaması veya örnek olması açısından tespit edilen iki tane lakap veriliş sebebine göre değerlendirilmiştir.

Mardinli: "Umudumuz Şaban" filmindeki "Mardinli" filim karakteri gibi giyindiği için tavır ve davranışlarının benzerliğinden dolayı bu lakap takılmıştır (K.K. 38).

Polat: Bu kişi malum zikredilen dizi karakterine fiziksel olarak benzediği için bu lakap takılmıştır (K.K. 38). 


\subsubsection{Bilgi, Yaş veya Tecrübeye Bağlı Olarak Verilen Lakaplar}

Bu başlık altında değerlendirilen lakaplar, kişinin bilgisine veya hayat tecrübesine dayalı verildiği tespit edilmiştir. Bu gibi lakaplar da çalışma sahamızda yöre halkının pek tercih etmediği müşahede edilmiştir. Tespitlerimize göre kişinin dini bilgi ve birikime göre (heco), yaşa bağlı olarak tecrübe sahibi olmasına (keko), Kur 'ani bilgisinden hareketle (hafız), medrese geçmişi olmasına (malla), sadece yaşının büyüklüğünden (pil) denildiği tespit edilmiştir. Aşağıda bu lakaplar ve veriliş nedeni ele alınmıştır:

Heco: Zazacada hacı demek olup ifade şekli heco'dur. İnsanlar bu kişinin bilgi ve tecrübesinden yararlanır. Köyde kişiler arası husumeti çözer. Köyde olumsuz bir davanın meydana gelmesi halinde çözüme kavuşması için kendisine başvurulur. Dini anlamda kişileri aydınlatır. Sohbet ve telkinleri dikkate alınır. Maddi ve manevi yardımlarının yanı sıra mülayim yumuşak ve yapıcı kişiliğinden hareketle bu lakap verilmiştir (K.K. 38).

Keko: Zazacada ağabey demek olup hitap hali keko'dur (V.Ç.G. 2009: 258). Bu kişi ailede yaş itibariyle büyük olması ve tecrübeli olmasından dolayı belirli işlerde kendisine başvurulduğundan dolayı bu lakap verilmiştir (K.K. 28).

Hafız: Bu kişi kuranı baştan sona ezbere okur. Dini anlamda bazı durumların çözülmesi için kendisine başvurulur. Dolaysıyla yöre halkı bu lakabı kendisine uygun görmüştür (K.K. 28).

Malla: Arapça molla, hoca demektir (Yılmaz, 2015: 86). Geçmişte medrese okumuştur. Dini bilgi ve tecrübeye sahiptir. Dolayısıyla halk kendisine bu lakabı takmıştır (K.K. 28).

Pil: Zazacada pil kelimesi yaşça büyük anlamında kullanılmaktadır. Lakap olarak kullanılmasının sebebi aynı isimde olan iki kişiyi birbirinden ayırt etmektir. Gül yaşça büyük olduğundan köydeki diğer Gül ismindeki kadından ayır etmek için "Gula pil”" demişler ve bu onun lakabı olarak kalmıştır (K.K. 60).

\subsection{Mensubiyete Dayalı Sülale Lakapları}

Ailede daha önceden yaşamış ya da hâlâ hayatta olan ve genellikle aile reisi/büyügü olan kişilerin isimlerine bağlı olarak o sülaleye veya o sülaleye mensup olan kişiye ad verilmektedir. Lakaplar konusunda tartışılan en önemli husus sülaledeki bir kişinin adından hareketle takılan ismin lakap olarak kabul edilip edilmemesidir. 
Derleme çalışması yaparken sülale isimlerinin lakap değil künye olduğunu savunan bazı kaynak kişiler ile tartışılmıştır. Buna delil olarak 1934 Soyadı Kanunu'na kadar ülkemizde kişiler; baba, sülale adları veya lakaplarıyla anılıyor, tanınıyordu. Soyadı Kanunu'ndan sonra genellikle eşraf, köklü aileler soyadlarının yanı sıra lakaplarıyla da anılmayı sürdürdüler. Çünkü aynı köy, kasaba veya şehirden birbirini yeni tanıyan iki kişi bir araya geldiğinde sordukları ilk soru; "Kimlerdensiniz?” olmaktaydı. Farklı şehirlerden iki kişi bir araya geldiğinde ise ilk tanışma sorusunun; "Nerelisin?” olduğunu biliyoruz (İzmirli, 2016: 103).

Bu konuda kriterimiz kaynak şahısların bilgileri, sahada nasıl kullanıldığı, kişilerin lakabı kullandığı bağlam ve lakap işlevini taşıyıp taşımadığı gibi hususlardır. Sülale lakaplarının büyük bir kısmı ailedeki bir kişinin isminden ya da sülale adından hareketle ortaya çıktığı görülmüştür. Bu konuda Şeref Boyraz şu görüşü savunur: Etnik kökeni, memleketi ve meslekleri bildiren sülale adları ortak kültürün bildiği manaları taşıdığı için lakap değildir. Eğer sülaleye adını veren kişinin bir lakabı var ise ve buradan hareketle sülaleye isimler verilmişse bunlara sülale lakabı demek yine mümkün değildir. Fakat isim, sülaleye teşbih yoluyla verilmişse lakaptır. Çünkü Kürtgil ismi o sülaleye Kürt kökenli olduklarından değil, sülalenin bireyleri dikkat çekici biçimde esmer oldukları için verilmiştir. Yani Kürtgil ismi "Kürtler çok esmerdir." bilincini taşıyan grup kültürünün bireyleri tarafından o sülaleye benzetme yoluyla verilmiştir. O halde Kürtgil kelimesi, kullanıldığı ortamda bu şekilde değerlendirildiği için sülalenin lakabıdır (Boyraz, 1997: 112).

Ancak normal hayatta insanlar aileleri en kısa yoldan nasıl tanımlamak isterler buna bakmak gerekmektedir. Onlar için ayırt edici ya da belirgin özellik neyse ona göre lakap verme yoluna gittikleri görülmektedir. Hiçbir zaman bütün aile bireylerinin taşıdığı ortak bir özelliği ya da buna benzer bir hususu kıstas almak gibi ayrıma gidilmemiştir. Ayrıca aynı ortamda, aynı işlev ve görevde kullanılan ifadeleri farklı adlandırmak ne kadar doğrudur? Bu konuda kullanılan bağlam göz önünde bulundurulmalıdır (Atlı, 2017: 105). Lakap takmak, eski bir gelenektir ve birçok millette vardır. Aynı ad taşıyan kişileri veya akraba aileleri birbirinden ayırmak amacıyla lakap takılması en yaygın uygulamadır Dolayısıyla sülale adları da lakap olarak alınması kanaatindeyiz.

Tespitlerimize göre lakaplar sülalede yaşamış veya hala yaşayan aile büyüğünün, annenin, babanın, dedenin ve sülalenin isminden hareketle verildiği tespit edilmiştir. Lakapların veriliş sebebi ailedeki büyügün ve sülale is- 
minden kaynaklandığı bilindiği için ayrıca veriliş sebebine değinilmemiştir. Dolayısıyla lakaplar herhangi bir farklılık arz etmediği için sadece lakapların isimleri ve anlamları zikredilmiştir.

\subsubsection{Anne İsmine Bağlı Olarak Verilen Lakaplar}

$\mathrm{Bu}$ başlık altında incelenen lakaplar kișinin annesinin isminden hareketle verildiği ve toplum tarafından kabul görüldügü tespit edilmiştir. Kişi anılırken kendi ismiyle değil annesinin ismiyle anılır ve böylece kim olduğu anlaşılır. Kişi kendi annesinin ismiyle öyle bütünleşmiş ki halk türkülerine bile annesinin ismiyle konu olmuştur. Örneğin "Sılêmun Emık mar çay demık hay dıle yemman... vb." Annenin ismine bağlı verilen lakapların örnekleri: (Sılêmun Emık), (Ehm Kib), (Mêd Pak), (Hes Bes), (Envêr Ayş), (El Hêw), (Êk Lut), (Tal Şef), (Rehim Hêwa). Bu lakapların anlamları, aşağıda alfabetik olarak ele alınmıştır:

Ehm Kib: Özel isim, Zazacada Ahmet ismi kısaltılarak Ehm şeklinde Kibar ismi ise Kib şeklinde ifade edilir. Bu kişinin annesinin adı Kibar'dır. Kişi annesinin ismiyle tanınır hale gelmiştir. Dolaysıyla halk Kibar oğlu Ahmet lakabını Ehm Kib şeklinde lakap olarak kullanmıştır (K.K. 37).

El Hêw: Özel isim, Zazacada Ali isminin ifade şekli El, Havva isminin ifade şekli ise Hêw'dir. Bu kişi annesinin ismiyle tanınır ve zikredilir. Dolaysıyla Havva oğlu Ali lakabı halk tarafından El Hêw şeklinde lakap olarak kullanmiştır (K.K. 34).

$\hat{E} k$ Lut: Özel isim, Zazacada Eyüp isminin ifade şekli Êk, Lütfiye'nin ise Lut'tur. Dolaysıyla halk Lütfiye oğlu Eyüp lakabını Êk Lut şeklinde lakap olarak kullanmıştır. (K.K.31).

Envêr Ayș: Özel isim, Zazacada Enver ismi herhangi bir değişikliğe uğramamıș. Ayşe ismi Zazacada Ayş şeklinde ifade edilir. Bu kişi annesinin ismi ile anılmış ve tanınmıştır. Dolaysıyla halk Ayşe oğlu Enver lakabını Envêr Ayş şeklinde lakap olarak kullanmıştır (K.K. 63).

Hes Bes: Özel isim, Hasan ismi Zazacada Hes Besila ismi ise Bes şeklinde ifade edilir. Kişinin annesinin adı Besila'dır. Besila oğlu Hasan lakabı halk tarafından Hes Bes şeklinde lakap olarak kullanmıştır (K.K. 28).

Mêd Pak: Özel isim, Muhittin ismi Zazacada Mêd, Pakize ismi ise Pak şeklinde ifade edilir. Bu kişinin ismi Muhittin, annesinin ismi ise Pakize'dir. Dolaysıyla halk Pakize oğlu Muhittin lakabını Mêd Pak şeklinde lakap olarak kullanmıştır (K.K. 37). 
Rehim Hêwa: Özel isim, Zazacada Rahim isminin ifade şekli Rehim, Havva isminin ifade şekli ise Hêw veya Hêwa'dır. Havva oğlu Rahim lakabı Rehim Hêwa keklinde kalmıştır (K.K. 28).

Sılêmun Emık: Özel isim, bu kişinin annesinin ismidir. Arapça kökenli olan Âmine isminin Türkçeleştirilmiş hali Emine olarak adlandırılır. Emine ismi Türkçe'den Zazaca'ya Em veya Emık şeklinde bozularak geçmiştir. Fatık, Emık, Remık, Zeynık, Elık, Samık, Hesık, vb. isimlerde bulunan “-ık, -mık, -nık” ekleri Türkçede kullanılan küçültme ekleri “cik, -ce, -cek, -ceğiz, -imsi, -imtırak, -rek" eklerine karşılık gelmektedir. Bu küçültme ekleri Türkçede olduğu gibi Zazacada da küçüklük, sevgi, şefkat, azlık, yakınlık, acıma gibi anlamlar yükleyen ekler olarak ifade edilebilir. Dolaysıyla halk Eminecik oğlu Süleyman lakabını Sılêmun Emık şeklinde lakap olarak kullanılmıştır (K.K. 37).

Tal Şef: Özel isim, Zazacada Talip isminin ifade şekli Tal, Şefika'nın ise Şef'dir. Dolaysıyla halk Şefika oğlu Talip lakabını Tal Şef şeklinde lakap olarak kullanmıştır (K.K. 37).

\subsubsection{Baba İsmine Bağlı Olarak Verilen Lakaplar}

Bu başlık altında incelenen lakaplar kişinin babasının isminden hareketle verildiği ve toplum tarafından kabul görüldüğü tespit edilmiştir. Araştırmamıza göre kişi anılırken kendi ismiyle değil babasının ismiyle anılır ve böylece kim olduğu anlaşılmıştır. Kişi kendi babasının ismiyle adeta bütünleşmiş halk türkülerine bile babasının ismiyle konu olmuştur. Örneğin: "Sılêmun Emer save sımer, Âdem Feti run çıkleti, Seid Seyfi meşke defi, Farday Musay korçyin resay hay dıle yemman ... vb." Baba ismine bağlı verilen lakapların örnekleri: (Adem Fêti), (Sılêmun Emêr), (Sıd Têhar), (Cum Ez), (Hus Xêl), (Yib Rêș), (Hus Wasmun ve Şuk Wasmun), (Vel Heci), (Ayşê Fêzi), Bu lakapların anlamları, aşağıda alfabetik olarak ele alınmıştır:

Adêm Fêti: Babasının adı Fethi'dir. Fethi ismi Türkçe'den Zazacaya Fêti şeklinde bozularak geçmiştir. Dolaysıyla bu lakap babasına nispet olarak verilmiş ve lakap olarak kullanılmıştır (K.K. 63).

Ayşê Fêzi: Özel isim, bu kişinin adı Ayşe, babasınınki Fevzi'dir. Zazalar Ayşe ismini Ayş, Fevzi ismini Fezi şeklinde ifade eder. Ayş ismindeki "ê" sesi Zazacada "-ê, - $-\hat{\imath}$ - -an" isim tamlamalarından bir tanesi olup Fevzi'nin (kızı) Ayşe anlamında kullanılmıştır. Dolaysıyla halk Fevzi'nin kızı Ayşe lakabını Ayşê Fêzi şeklinde lakap olarak kullanmıştır (K.K. 28). 
Cum Ez: Özel isim, bu kişinin adı Cuma Babasının adi Aziz'dir. Zazalar Cuma ismini Cum, Aziz ismini Ez şeklinde ifade eder. Dolaysıyla Aziz oğlu Cuma lakabı halk tarafından Cum Ez şeklinde lakap olarak kullanmıştır (K.K. 28).

Hus Xêl: Özel isim, bu şahsın adı Hüseyin, babasının adı ise Halef'tir. Zazalar Hüseyin ismini Hus, Halef ismini Xêl şeklinde ifade eder. Halk Halef oğlu Hüseyin lakabını Hus Xêl şeklinde lakap olarak kullanmıştır (K.K. 37).

Hus Wasmun ve Şuk Wasmun: Özel isim, Bu kişiler kardeştir. Adları Hüseyin ve Şükrü'dür. Babalarının adı ise Osman'dır. Zazalar Hüseyin ismini Hus, Şükrü ismini Şuk, Osman ismini ise Was şeklinde ifade eder. Dolaysıyla Osman oğlu Hüseyin ve Şükrü lakapları halk tarafından Hus Wasmun, Şuk Wasmun şeklinde lakap olarak kullanmıştır (K.K. 28).

Sılêmun Emêr: Özel isim, bu kişinin babasının ismidir. Emer ismi Arapça kökenli Ömer isminden bozularak Zazacaya geçmiştir. Zaza halkı Ömer ismini Emêr şeklinde kullanır. Dolayısıyla halk Ömer oğlu Süleyman lakabını Sılêmun Emêr şeklinde lakap olarak kullanmıştır (K.K. 37).

Sıd Têhar: Özel isim, bu kişinin adı Sıddık babasının ise Tahir'dir. Sıd Arapça kökenli olan Sıddık isminden Têhar ise Tahir isminden bozularak Zazacaya geçmiştir. Zaza halkı Sıddık ismini Sıd, Tahir ismini ise Têhar şeklinde ifade eder. Dolaysıyla halk Tahir oğlu Sıddık lakabını Sıd Têhar şeklinde lakap olarak kullanmıştır (K.K. 63).

Sıdqi Mallay: Sıdqi Mallay'ın babası geleneksel medrese eğitim gören birisi olduğu için Zazaca Malla sıfatıyla isimlendirilmektedir. Malla Zazacada dini ilimlere vakıf, cami hocası, âlim hoca anlamında kullanılan bir kelimedir. Sıdqi Mallay bir isim tamlamasıdır. Malla, babasının mesleğinden dolayı babasına verilen lakaptır, dolayısıyla Sıdqi de babasının ismi yerine bu lakapla anılmaktadır (K.K. 28).

Yib Rêş: Özel isim, kişinin adı İbrahim, babasının adı Reşat'tır. Zaza halkı İbrahim ismini Yib, Reşat ismini ise Rêş şeklinde ifade eder. Dolaysıyla Reşat oğlu İbrahim lakabı halk tarafından Yib Rêş şeklinde lakap olarak kullanmıştir (K.K. 63).

Vel Heci: Özel isim, kişinin adı Veli babasının ise Hacı'dır. Zazalar Veli ismini Vel, Hacı ismini Heci şeklinde ifade eder. Dolaysıyla Hacı oğlu Veli lakabı halk Vel Heci şeklinde lakap olarak kullanmıştır (K.K. 63). 


\subsubsection{Sülaleye Bağlı Olarak Verilen Lakaplar}

Çalışma sahamızda tespiti yapılan sülaleye dayalı lakaplar oldukça fazladır. Bu tür lakapların anlam ve veriliş nedeni hakkında bir farklılık olmadığı için bütün lakaplara burada değinilmemiştir. Dolayısıyla bu lakapların sadece bir kaçına değinilmiş anlam ve veriliş nedeni ele alınmıştır. Sülale ismine bağlı verilen lakapların örnekleri: (Mehmedun), (Murun), (Xêlefon), (Wusun), (Hoşun), (Qeşun), (Elun). Bu lakapların anlam ve örnekleri aşağıda alfabetik olarak sıralanmıştır:

Elun: Özel isim, bu ailenin sülalesinin ismidir. Arapça kökenli bu isim Zazacaya El şeklinde bozularak geçmiştir. “-Un” eki de Zazacadaki "-ler, -lar" anlamındaki iki çokluk ekinden birisidir Elun kelimesindeki "-Un" eki Türkçedeki çoğul eki "-ler, -lar, -gil, -giller, -oğulları -sülalesi” eklerinin anlamını karşılamaktadır. Dolayısıyla kelimeye çoğul anlamı katarak topluluk ismi oluşturmuştur. Elun kelimesi, Aliler, Alioğulları, anlamında lakap olarak kullanılmıştır. Örnek: Eli Elun (Alioğulları sülalesinden Ali) (K.K. 63).

Hoşun: Ailenin sülalesinin lakabıdır. Sözlükte hoş kelimesinin anlamı avlu, evin avlusu şeklinde geçmektedir. (Yılmaz, 2015: 68). “-Un” eki de Zazacadaki "-ler, -lar" anlamındaki iki çokluk ekinden birisidir. Dolaysıyla - “-Un” eki kelimeye çoğul anlamı katarak topluluk ismi oluşturmuştur. Araştırmamıza göre sülale El Hoş'a nispet edilerek hoşun lakabını almıştır. El Zazacada Ali isminin ifade şeklidir. Dolaysıyla Ali'ye neden hoş lakabı takıldığı anlaşılmamıştır. Örnek: El Hoşun (Hoşun sülalesinden Ali) (K.K. 37).

Mehmedun: Özel isim, ailenin sülalesinin ismi Mehmet'tir. Mehmedun kelimesindeki “-Un” eki Türkçede "-ler, -lar, -gil, -giller, -oğulları -sülalesi” eklerinin anlamını karşılamaktadır. Dolayısıyla bu ek kelimeye Mehmetoğulları veya sülalesi anlamını vererek topluluk ismi oluşturmuştur. Örnek: Hes Mehmedun (Mehmet sülalesinden Hasan) (K.K. 63).

Murun: Özel isim, ailenin sülalesinin ismidir. Murat ismi Zazacada Mur şeklinde ifade edilir. “-Un” eki de Zazacadaki “-ler, -lar” anlamındaki iki çokluk ekinden birisidir. Ayrıca Zazaca "-Un” eki Türkçedeki "-ler, -lar, -gil, -giller, -oğulları -sülalesi” eklerinin anlamını karşılamaktadır. Dolayısıyla "-Un" eki kelimeye çoğul anlamı katarak topluluk ismi oluşturmuştur. Kelime, Muratoğulları, Muratgiller, Murat sülalesi anlamı alarak lakap olarak kullanılmıştır. Örnek: Zufêr Murun (Murat sülalesinden Zafer) (K.K. 63).

Qeşun: Özel isim, bu ailenin sülalesinin ismidir. Qêş Zazacada özel isim olarak kullanılmakla birlikte anlamı anlaşılmamıştır. “-Un” eki de Zazacadaki 
“-ler, -lar" anlamındaki iki çokluk ekinden birisidir. Ayrıca Zazaca "-Un" eki Türkçedeki "-ler, -lar, -gil, -giller, -oğulları -sülalesi" eklerinin anlamını karşılamaktadır. Dolayısıyla "-Un" eki kelimeye çoğul anlamı katarak topluluk ismi oluşturmuştur. Qeşun kelimesi, Qeş ailesi, Qeş sülalesi veya Qeşoğulları anlamında lakap olarak kullanılmıştır. Örnek: Reşat Qeșun (Qeş sülalesinden Reşat) (K.K. 63).

Wusun: Özel isim, ailenin sülalesinin ismi Yusuf'tur. Yusuf ismi Türkçeden Zazacaya Wus şeklinde bozularak girmiştir. Wusun kelimesindeki "-Un" eki Türkçede "-ler, -lar -gil -sülalesi" eklerinin anlamını karşılamaktadır. Dolayısıyla bu ek kelimeye Yusufoğulları veya Yusuf sülalesi anlamını vererek topluluk ismi oluşturmuştur. Örnek: Wus Wusun (Yusuf sülalesinden Yusuf) (K.K. 63).

Xêlefun: Özel isim, bu ailenin sülalesinin ismidir, Arapça kökenli bir isimdir, ikincil, vekil, kalfa, halife gibi anlamlara gelmektedir. “-Un" eki de Zazacadaki "-ler, -lar" anlamındaki iki çokluk ekinden birisidir. Kelimeye Halefler anlamı vererek topluluk ismi olmasını sağlamıştır. Zazaca "-Un" eki Türkçedeki "-ler, -lar, -gil, -giller, -oğulları -sülalesi" eklerinin anlamını karşılamaktadır. Dolayısıyla Xêlefun kelimesi de Halefler, Halefgil, Halefgiller, Halefoğulları, Halef sülalesi şeklinde anlamlandırılabilir. Örnek: İs Xêlefun (Xêlefoğulları sülalesinden İsmail) (K.K. 63).

\section{SONUÇ}

Yapılan derleme çalışması sonucunda, Zazaca konuşan halk arasında lakap takma geleneğinin canlılığını hâlâ belirgin bir biçimde devam ettirdiği görülmektedir. Çalışma sadece Emtağ köyünde kullanılan lakaplarla sınırlı tutulmuştur. Gözlem ve araştırma sonucunda lakaplar Emtağ köyünde fazla kullanıldığı için bu anlamda köye de bir lakap takıldığı gözlemlenmiştir. Civar köy ve mahalleler bu bağlamda köyü "Dero Fesat" Fesat Deresi lakabiyla tanımlamışlardır.

Elde edilen Zazaca lakaplar, yöre halkının birbirleriyle sıkı ve samimi ilişkilerinin olduğunu, kişilerin yaşanan olaylar ve durumlar karşısında gözlem ve değerlendirme kabiliyetinin ne kadar güçlü olduğunu göstermiştir. Lakap takılırken seçilen ifadelerin kişinin karakter ve mizacıyla ne derece uyumlu olduğunu göstermesi bakımının önemlidir. Bu da kişilerin yaratıcılık ve mizahî yönlerinin ve gözlem gücünün ne kadar iyi olduğunun göstergesidir.

Çalışma yapılırken fark edilen başka bir husus da şudur: Halkın lakaplarla olan ilişkisi öyle sıkı ve geniş ki nerdeyse yöre halkının tümünün bir lakabı- 
nın olduğunu söylemek mümkündür. Bu durum yöre halkının kültür seviyesini, gözlem gücünü, mizahi anlayışını göstermektedir. Lakaplar takılırken kişilerin bir kusuruna, davranış şekline, giyim ve kuşamına, temizliğine, dış görünüşüne göre verildiği tespit edilmiştir.

Yörede sadece erkekler arasında değil kadınlar arasında da lakap takma geleneğinin yaygın olduğu görülmüştür. Derleme sırasında kadınlardan sağlıklı bilgi alınamamasına rağmen görüşülen kaynak kişilerin ifadeleri ve elde edilen lakaplar bu görüşü destekler niteliktedir.

Çalışmada tespiti yapılan lakapların temel işlevlerinin tarif etmek/tanıtmak, küçük düşürmek, sülaleye dayalı lakaplar ve nesiller arasında bağ kurmak olduğu görülmektedir. Bu bağlamda kişilerin davranış şekillerine, karakteristik özeliğine göre takılan lakaplar ve sülaleye dayalı takılan lakapların çoğunlukta olduğu görülmüştür.

Bingöl'ün Emtağ köyünde yapılan lakap incelemesi, Zaza dili ve edebiyatı için önem taşımakla birlikte bu tür çalışmaların ilklerinden biri olarak ele alınmıştır. Dolayısıyla bu çalışma esas alınarak Bingöl ili veya herhangi bir ilçesi hakkında daha ayrıntılı bir çalışma yapılabilir. 


\section{Bingöl ARAŞTIRMALARI DERGisi}

\section{Kaynakça}

\section{Yazılı Kaynaklar}

AKDAĞ, Ömer, “Çeșmelisebil'de Lakaplar ve 1934 Lakap Kanunu”, Tarih, Kültür, Sanat, Turizm ve Tarım Açısından Uluslararası Sarayönü Sempozyumu (24-26 Ekim 2014 Konya) Bildiri Kitabı, 8, Konya 2015, ss. 725-734.

AKSAN, Doğan, Her Yönüyle Dil-Ana Çizgileriyle Dilbilim, Cilt: 1-2-3, Ankara 2003.

ATSIZ, Bedriye, "Lâkaplar", Tarih ve Toplum Aylık Ansiklopedik Dergi, Kasım, Sayı: 11, (1984), ss. 26-28.

ATLI, Sagıp, “Manisa'nın Demirci İlçesindeki Lakaplar Üzerine Bir İnceleme” CÜ Sosyal Bilimler Dergisi, Haziran Cilt: 41, Sayı: 1. (2017), ss. 102-131.

BOYRAZ, Şeref, "Lakaplar Konusunda Bazı Dikkatler ve Bir Yöre Örneği”, Türklük Bilimi Araştırmaları, Sayı: VII, (1998), ss. 107-138.

BOZKURT, Nebi, “Lakaplar”, İA, Cilt: 27, İstanbul 2003, ss. 65-67.

ÇOŞAR, Asiye Mevhibe, "Trabzon'da Kullanılan Lakaplar Üzerine Bir Derleme/Değerlendirme”, TDAY-Belleten, Cilt: 1, (2003), ss. 27-40.

DUNDES, Alan, “Halk Kimdir?”, Çev. M. Ekici. "Halk Biliminde Kuramlar ve Yaklaşımlar” 1 (Yay. Haz.: M. Öcal Oğuz vd.) Ankara 2006), s. 11-26.

EKİNCI, Ramazan, Uşşâkîzâde Hasib'in Zeyl-i Şakâiki (İnceleme-Metin Dizin), Basılmamış Doktora Tezi, Manisa: Celal Bayar Üniversitesi Sosyal Bilimler Enstitüsü, Manisa 2014.

GRÛBA XEBATE YA VATEYÎ, Türkçe-Kırmancca (Zazaca) Sözlük, Wesanxaneyê Vateyî (Genişletilmiş 3. Baskı), İstanbul 2009, s. 625.

İZMİRLİ, Yücel, “Rodos/Rodoslu Türklerin Lakapları”, İzmir 2016.

KARATAȘ, Pınar, "Hekim Folklorunda Stereotiplerin Lakapları Şekillendirmesi ve Fıkralara Yansımaları". Millî Folklor, Y. 29. S. 116. (2017), s.129- 142.

KARDAȘ, Canser, "Muș İli Merkezinde Kullanılan Erkek Lakapları" Motif Akademi Halkbilimi Dergisi, Cilt: 11, Sayı: 23, (2018), s. 207-226.

KAYA, Doğan, Türk Dünyası Ansiklopedik Türk Halk Edebiyatı Kavramları ve Terimleri Sözlüğü. Ankara 2014.

KESKİNKILIÇ, Esra, "Sultani Lakaplar (veya Devletlü ve Saadetlü Lakaplar)", Acta Turcica, "Kültürümüzde İsim”, ed: Emine Gürsoy Naskali, Hilal Oytun Altun, Yll: VI, Sayı: 1-1, Ocak, (2014), ss. 1-22.

KOMISYON, Türkçe Sözlük. Türk Dil Kurumu Yayınevi, Ankara 1998.

KÖSE, Nerin, “Marmaris'te Soy-Sülale Adları Üzerine”, Muğla Kitabı, hzl: Ali Abbas Çınar, İzmir: Printer Ofset, (2004), ss. 269-280.

ÖZDEMIR, Seyhan ve Ramazan ERDEM "Akademik Örgütlerde İdarî Personel Arasında Kullanılan Lakap Üzerine Bir Çalıșma”, V. Türkiye Lisansüstü Çalışmaları Kongresi-Bildiriler Kitabı I, 12-15 Mayıs 2016, Isparta, ss.

ÖZKAN, Nevzat, “Adlandırma Yöntemi Olarak Lakaplar ve Büyükkışla'daki Örnekleri", I. Uluslararası Bozok Sempozyumu 05-07 Mayıs 2016 Bildiri Kitabı, Cilt: 3, (2016), ss. 180-189. 
ÖZTÜRK, Jale, “Antakya Köylerinde Lakaplar”. Dr. Mehmet Tekin'e Armağan. (Edt. Sacit Oğuz-Bülent Arı), s. 262-281, (2016), İskenderun: Mustafa Kemal Üniversitesi Yayını.

SAKAOĞLU, Saim, Türk Ad Bilimi I Giriş, Ankara: Türk Dil Kurumu Yayınları 2001.

WALTER J. Ong, Sözlü ve Yazılı Kültür, (Çev. Sema Postacıŏlu Banon) İstanbul: Metis Yayınları 1999.

YILMAZ, Abdurrahman, Zazaca-Türkçe Sözlük (Genç-Bingöl Yöresi), Yüksek Lisans Tezi, (2015), Bingöl Üniversitesi

\section{Internet Kaynakları}

(www.mevzuat.gov.tr erişim tarihi 22.04.2021).

(https://sozluk.gov.tr erişim tarihi 04.05.2021).

(https://tr.wikipedia.org erişim tarihi 04.05.2021).

(https://www.youtube.com/watch?v=yVL7qSNCXck Erișim Tarihi: 24.03.2021).

\section{Sözlü Kaynaklar ${ }^{4}$}

K.K.1: Ayşe Çaça, 1964, İlkokul, Ev Hanımı, Merkez/Elazı ̆̆

K.K.2: Bekir Elleri, 1990, Üniversite, Kuyumcu, Merkez/Bingöl.

K.K.3: Bünyamin Bulukgiray, 1998, Üniversite, Mimar, Emtağ/Bingöl.

K.K.4: Belkıs Yıldız, 1985, İlkokul, Ev Hanımı, Karakoçan/Elazığ.

K.K.5: Doğan Çaça, 1984, İlkokul, İşçi, Merkez/Elazığ.

K.K.6: Enes Bulukgiray, 1991, Lise, Esnaf, Merkez/Bingöl.

K.K.7: Eyüp Giray, 1989, Lise, Balcı, Emtağ/Bingöl.

K.K.8: Emine Baybarz, 1998, Ortaokul, Ev Hanımı, Merkez/İstanbul.

K.K.9: Fatih Giray, 1991, Lise, İşçi, Emtağ/Bingöl.

K.K.10: Hasan Bulukgiray, 1958, ilkokul, Çalışmıyor, Emtağ/Bingöl.

K.K.11: İsa Bulukgiray, 1992, Üniversite, Öğrenci, Merkez/Bingöl.

K.K.12: Kadri Sağdıç, 1989, Üniversite, Balcı, Merkez/Bingöl.

K.K.13: Kübra Bulukgiray, 2004, Lise, Öğrenci, Emtağ/Bingöl.

K.K.14: Mehdi Elleri, Üniversite, 1983, Müteahhit, Merkez/Bingöl.

K.K.15: Melek Okşan, 1989, İlkokul, Ev Hanımı, Merkez/Elazı̆̆.

K.K.15: Muhittin Bulukgiray, 1983, Lise, Çiftçi, Emtağ/Bingöl.

K.K.17: Musa Bulukgiray, 1981, İlkokul, İşçi, Emtağ/Bingöl.

K.K.18: Osman Basatemür, 1990, Üniversite, Balcı, Merkez/Bingöl.

K.K.18: Rıdvan Çağatay, 1989, Üniversite, Esnaf, Merkez/Bingöl.

K.K.20: Rabia Bukebudraç, 1979, İlkokul, Ev Hanımı, Merkez/Bingöl.

K.K.21: Salisa Bulukgiray, 1957, Okur Yazar Değil, Ev Hanımı, Emtağ/Bingöl

K.K.22: Sevim Karabulut, 1987, İlkokul, Ev Hanımı, Merkez/Elazığ.

4 Kaynak kişilerin künyeleri "adı, soyadı, doğum tarihi, eğitim durumu, mesleği ve ikamet adresi" sıralamasıyla verilmiştir. Metin içerisinde ise gönderme yapılan kaynak kişiler "K.K.1" örneğinde olduğu gibi kısaltılarak verilmiştir. 


\section{BINGÖL ARAŞTIRMALARI DERGISİ}

K.K.23: Siraç Bulukgiray, 1997, İlkokul, İşçi, Emtağ/Bingöl.

K.K.24: Sıdıka Bukebudraç, 1951, İlkokul, Ev Hanımı, Merkez/Bingöl.

K.K.25: Saim Bukebudraç 1973, Lise, Güvenlik, Merkez/Bingöl.

K.K.26: Ümit Çaça, 1993, Lise, İşçi, Emtağ/Bingöl.

K.K.27: Yusuf Taş, 1991, Üniversite, Gazeteci, Merkez/Bingöl.

K.K.28: Zeynep Bulukgiray, 1994, Üniversite, Öğretmen, Merkez/Bingöl.

K.K.29: Zeynep Bulukgiray, 1981, İlkokul, Ev Hanımı, Emtağ/Bingöl.

K.K.30: Ziyadin Bulukgiray, 1988, Lise, Turizm, Merkez/Bingöl, 
